Final Report

FHWA/IN/JTRP-2004/17

\title{
The Use of Vegetation in the Stabilization, Reclamation, and Remediation of Impacted INDOT Soils
}

\author{
by \\ Mark S. McClain \\ Graduate Research Assistant \\ and \\ M. Katherine Banks \\ Professor \\ School of Civil Engineering \\ and \\ A. Paul Schwab \\ Department of Agronomy \\ Purdue University \\ Joint Transportation Research Program \\ Project No. C-36-68T \\ File No. 4-7-20 \\ SPR-2624 \\ Prepared in Cooperation with the \\ Indiana Department of Transportation and the \\ U.S. Department of Transportation \\ Federal Highway Administration
}

The contents of this report reflect the views of the author who is responsible for the facts and the accuracy of the data presented herein. The contents do not necessarily reflect the official views or policies of the Indiana Department of Transportation or the Fedeeral Highway Administration at the time of publication. This report does not constitute a standard, specification, or regulation.

Purdue University

West Lafayette, Indiana 47907

October 2004 


\section{TECHNICAL Summary}

INDOT Research

Technology Transfer and Project Implementation Information

TRB Subject Code: 23-8 Ecological Abatement

Publication No.: FHWA/IN/JTRP-2004/17, SPR-2624

October 2004

Final Report

\section{The Use of Vegetation in the Stabilization, Reclamation, and Remediation of Impacted INDOT Soils}

\section{Introduction}

Soils can be severely impacted by transportationrelated activities including highway construction, renovations, maintenance, and accidental spills. Reclamation or remediation of soils contaminated by salts, solvents, paints, petroleum, and metals may be necessary to comply with current environmental regulations and to avoid erosion of denuded areas. Vegetation as alternative for INDOT facilities in the remediation of contaminated soils and groundwater has not been fully explored.

Many uses have been found for vegetation in the recovery of disturbed and contaminated land. For example, the establishment of ground cover to prevent erosion has been used for many decades. Some fascinating and innovative uses for vegetation have been developed very recently, such as the extraction of arsenic from pesticidecontaminated soil using a fern.
Phytoremediation uses plants to degrade, extract, contain, or immobilize contaminants from soil and water. Phytoremediation is an innovative, costeffective alternative to more conventional treatment methods used in the remediation of hazardous waste sites.

The major goal of this project was to write the manual PhytoRemediate $^{\circledR}$ : Phytoremediation Decision Guide for Transportation Engineers and the attached compact disk PhytoRemediate ${ }^{\circledR}$ : Training Module for Transportation Engineers to assist transportation engineers and other professionals in the applicability of phytoremediation as an effective method of remediation engineering design. This guide is not a design manual, but identifies the decision-making processes necessary for successful remediation of contaminated sites using phytoremediation.

\section{Findings}

The major findings of this project are the writing of the manual PhytoRemediate ${ }^{\circledR}$ : Phytoremediation Decision Guide for Transportation Engineers and the attached compact disk PhytoRemediate ${ }^{\circledR}$ : Training Module for Transportation Engineers.

The objectives of the manual and training module are to:

- Provide a decision guide for transportation engineers to evaluate the applicability of phytoremediation to contaminated sites. Phytoremediation projects have been proposed or applied to ecosystem restoration and soil, surface water, groundwater, and sediment remediation. This decision guide identifies and defines phytoremediation technologies, and provides examples of current research and case studies to aid in the evaluation of proposed phytoremediation applications.

- Develop a decision guide that is accessible for the Indiana Department of Transportation (INDOT) and the Indiana Department of Environmental Management (IDEM) teams and others to evaluate alternative remediation technologies.

- Present phytoremediation system characteristics that transportation engineers and other professionals need to assess the 
potential applicability of phytoremediation to specific contaminated sites.

Present a summary of select case studies and their applicability to environmental problems identified by the Indiana Department of Transportation (INDOT), illustrating actual field applications of phytoremediation.

\section{Implementation}

The major findings of this project are the writing of the manual PhytoRemediate $^{\circledR}$ : Phytoremediation Decision Guide for Transportation Engineers and the attached compact disk PhytoRemediate ${ }^{\circledR}$ : Training Module for Transportation Engineers.

The objectives of the manual and training module are to:

- Provide a decision guide for transportation engineers to evaluate the applicability of phytoremediation to contaminated sites. Phytoremediation projects have been proposed or applied to ecosystem restoration and soil, surface water, groundwater, and sediment remediation. This decision guide identifies and defines phytoremediation technologies, and provides examples of current research and case studies to aid in the evaluation of proposed phytoremediation applications.

- Develop a decision guide that is accessible for the Indiana Department of Transportation (INDOT) and the Indiana Department of Environmental Management (IDEM) teams and others to evaluate alternative remediation technologies.

- Present phytoremediation system characteristics that transportation engineers and other professionals need to assess the potential applicability of phytoremediation to specific contaminated sites.

Present a summary of select case studies and their applicability to environmental problems identified by the Indiana Department of Transportation (INDOT), illustrating actual field applications of phytoremediation

\section{Contacts}

For more information:

Prof. M. Katherine Banks

Principal Investigator

School of Civil Engineering

Purdue University

West Lafayette IN 47907

Phone: (765) 496-3424

Fax: (765) 496-1107

E-mail: kbanks@ecn.purdue.edu

Prof. A. Paul Schwab

Principal Investigator

Department of Agronomy

Purdue University

West Lafayette IN 47907

Phone: (765) 496-3602

Fax: (765) 496-2926

E-mail: pschwab@purdue.edu

\section{Indiana Department of Transportation}

Division of Research

1205 Montgomery Street

P.O. Box 2279

West Lafayette, IN 47906

Phone: (765) 463-1521

Fax: (765) 497-1665

Purdue University

Joint Transportation Research Program

School of Civil Engineering

West Lafayette, IN 47907

Phone: (765) 494-9310

Fax: (765) 496-7996

jtrp@ecn.purdue.edu

http://www.purdue.edu/jtrp 


\section{PhytoRemediate $^{\circledR}$ :}

\section{Phytoremediation Decision Guide for Transportation Engineers}

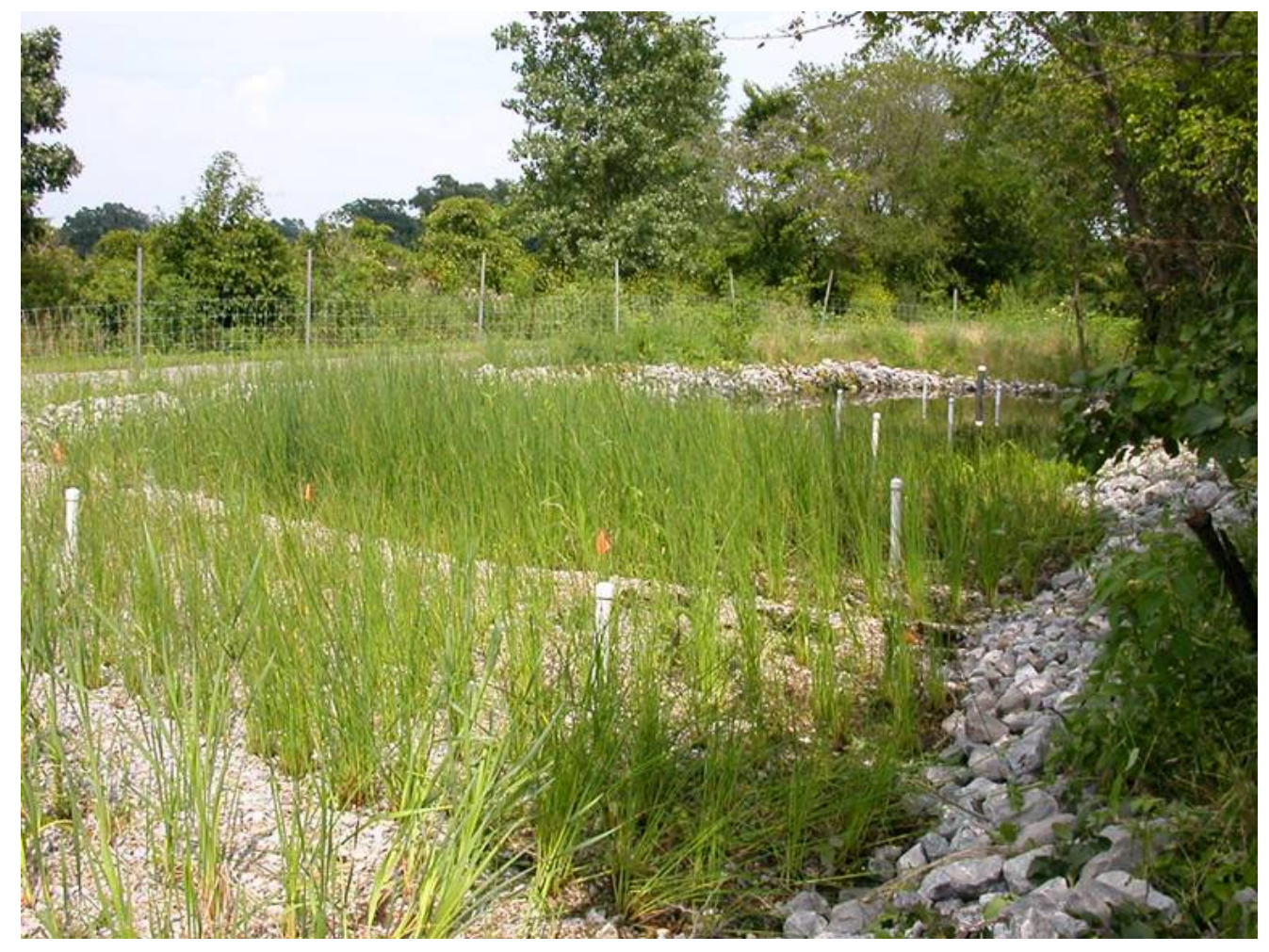

Mark S. McClain

M. Katherine Banks

A. Paul Schwab

May 2004 


\section{PURDUE UNIVERSIY \\ SCHOOL OF CIVIL ENGINEERING \\ JOINT TRANSPORTATION RESEARCH PROGRAM}

1. Project Identification: Indiana SPR-2624

656-1284-0228 \& 656-1150-0229

File No. 4-7-20

Project Title: The Use of Vegetation in the Stabilization, Reclamation, and Remediation of Impacted INDOT Soils

Principal Investigators: M. Katherine Banks and A. Paul Schwab

2. Date Started: May 1, 2002

3. Completion Date: August 31, 2004

4. Research Agency: Joint Transportation Research Program, Purdue University

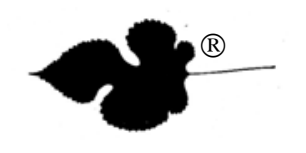

PhytoRemediate $^{\circledR}$ : Phytoremediation Decision Guide for (C)2004 Purdue University Transportation Engineers 


\section{Acknowledgments}

Principal Investigators: M. Katherine Banks and A. Paul Schwab (Purdue University).

Graduate Research Assistant: Mark McClain

Science Advisory Committee: Barry Partridge, Jay Head, David Lamb, Chris Dillman, Robert Buskirk, and Tom Duncan (INDOT); and Matt Fuller (FHWA).

Tom Duncan, Acting Environmental Services Manager, INDOT and Don Arnold, Environmental Services Section, INDOT for their cooperation in providing invaluable information relative to the environmental problems that the agency confronts.

Vibhav Mankad for his initial investigation with INDOT.

Katy Eulis and James Hunter for providing photographs and summaries of their research on INDOT projects.

Susan and Mary McClain for their assistance in the computer applications.

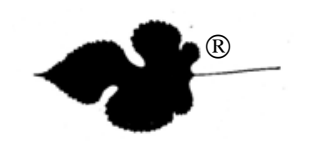

PhytoRemediate ${ }^{\circledR}$ : Phytoremediation Decision Guide for (C2004 Purdue University Transportation Engineers 


\section{Disclaimers}

Information in the many World Wide Web pages that are linked to PhytoRemediate ${ }^{\circledR}$ comes from a variety of sources. Some of this information is from official Purdue University pages, but much of it comes from unofficial or unaffiliated organizations and individuals, both internal and external to the University. Purdue University does not necessarily author, edit, or monitor these unofficial pages and therefore cannot assume responsibility for their content.

All contents Copyright (C 2004 Purdue University. All rights reserved. PhytoRemediate ${ }^{\circledR}$ is an official World Wide Web page of Purdue University. 


\section{Table of Contents}

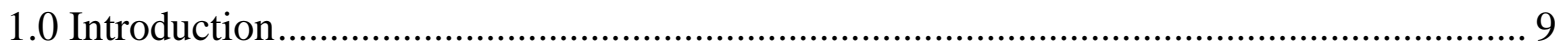

1.1 Purpose of Design Guide and Intended Audience …………………….................. 9

1.2 Objective of Design Guide................................................................................. 10

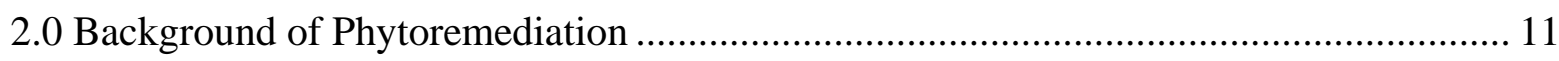

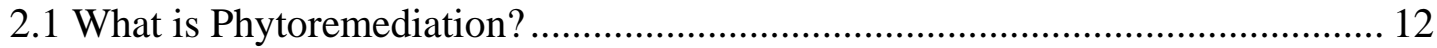

2.2 Brief History of Phytoremediation.......................................................................... 13

2.3 Basic Types of Phytoremediation: Processes and Mechanisms ........................... 14

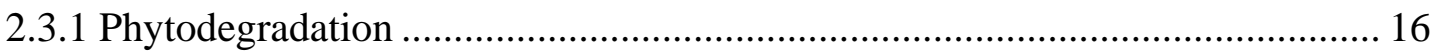

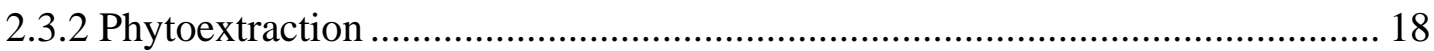

2.3.3 Containment and Immobilization of Contaminants ........................................... 19

2.3.4 Phytoremediation Applications...................................................................... 20

2.4 Technical Considerations for Phytoremediation.................................................... 23

2.5 Economic Considerations for Phytoremediation .................................................. 24

2.5.1 Phytoextraction Costs ................................................................................... 25

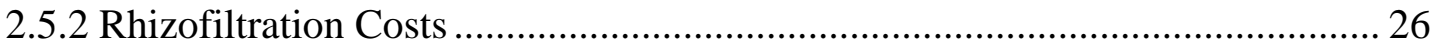

2.5.3 Phytostabilization Costs .................................................................................. 26

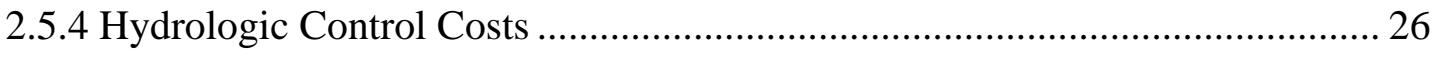

2.5.5 Vegetative Cover Costs.................................................................................. 27

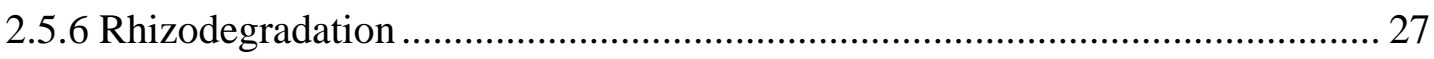

2.5.7 Phytoremediation Cost Comparisons and Estimates ......................................... 27

2.6 Environmental Problems Identify by the Indiana Department of

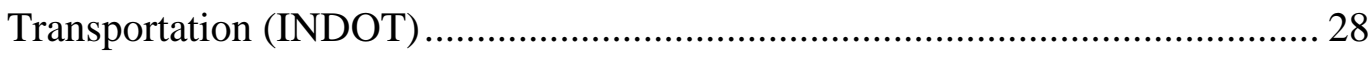

3.0 Phytoremediation Case Studies......................................................................................... 33

3.1 J-Field, Aberdeen Proving Ground ................................................................................ 34

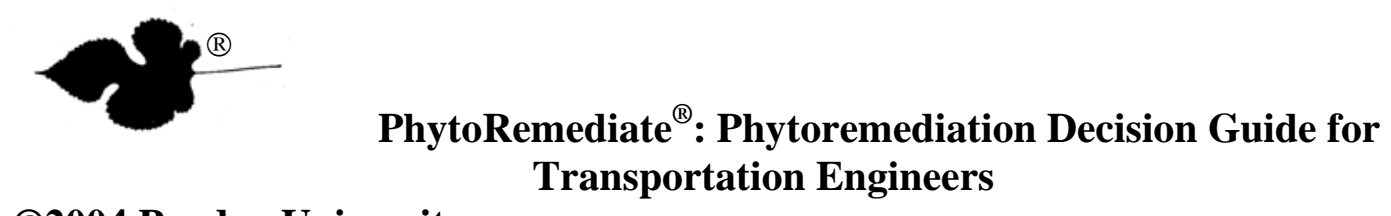

(C2004 Purdue University 
3.2 Kauffman \& Minteer, Jobstown, New Jersey ........................................................ 35

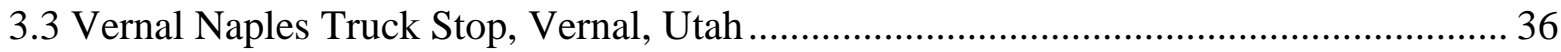

3.4 Tibbetts Road, Barrington, New Hampshire............................................................ 37

3.5 Former Chevron Light Petroleum Products Terminal, Ogden, Utah............................. 38

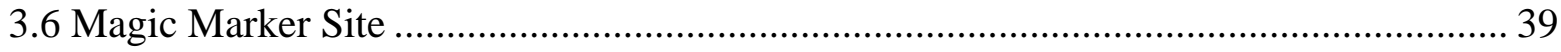

3.7 Constructed Wetlands for the Remediation of Slag Leachates................................... 40

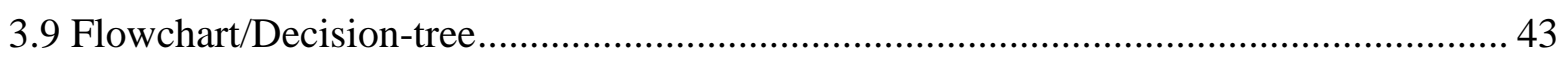

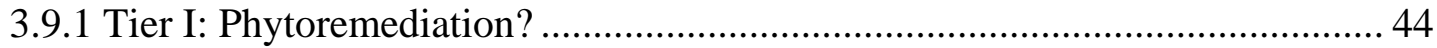

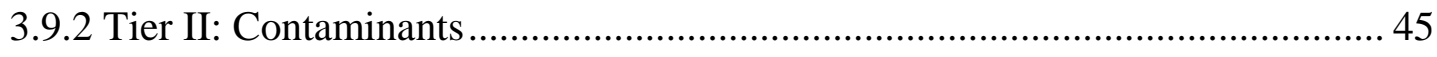

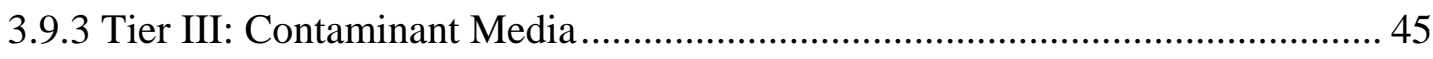

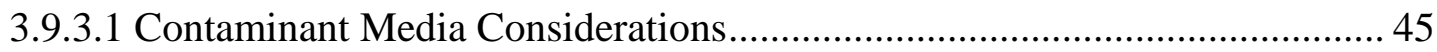

3.9.3.3 Phytoremediation of Contaminant Media: Soil, Sediment, and Sludge ........ 46

3.9.3.4 Phytoremediation of Contaminant Media: Groundwater............................. 47

3.9.3.5 Phytoremediation of Contaminant Media: Surface Water ........................... 47

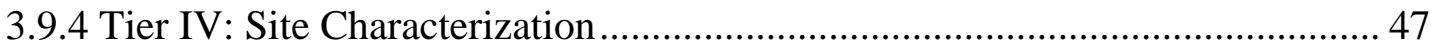

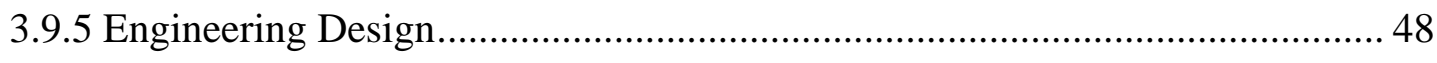

3.9.6 Phytoremediation System Selection and

Engineering Design Considerations......................................................... 49

4.0 PhytoRemediate ${ }^{\circledR}$ : Preliminary Phytoremediation Design Checklist ............................ 51

5.0 Plant Selection Process for Phytoremediation ........................................................ 54

6.0 Internet Resources on Phytoremediation ............................................................ 56

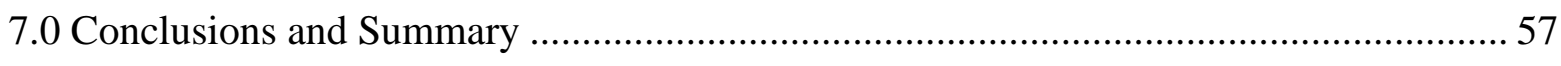

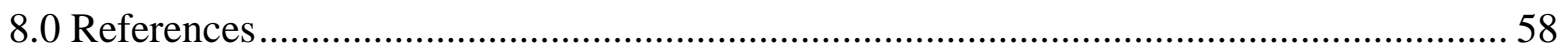

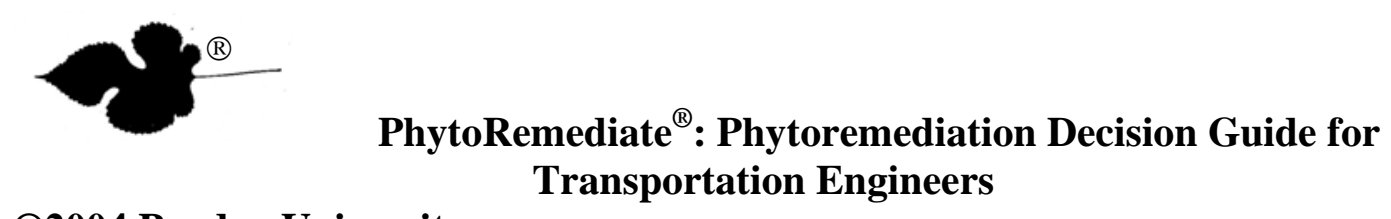

(C)2004 Purdue University

\section{Transportation Engineers}




\section{List of Figures}

Figure 1 Many plants have been used for the phytoremediation of PAHs and PCBs

Figure 2 Soil sampling for site characterization for phytoremediation site clean-up in

Bedford, Indiana 11

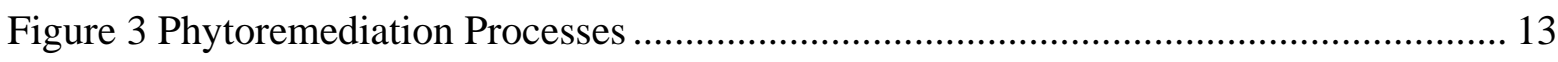

Figure 4 Phytoremediation pioneer Kathy Banks and student in the laboratory .................. 14

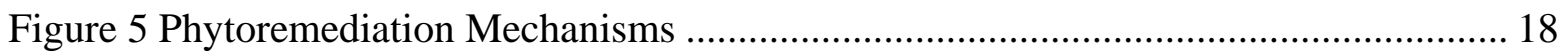

Figure 6 Excavator removing an underground storage tank ......................................... 31

Figure 7 Many INDOT bridges have been painted with lead-based paint ......................... 31

Figure 8 Soil erosion control implemented by INDOT ............................................... 33

Figure 9 Phytoremediation greenhouse study .......................................................... 40

Figure 10 Interstate 65 site in May 2002 ................................................................ 41

Figure 11 Interstate 65 site in late July 2003 showing the constructed wetlands ................ 42

Figure 12 Decision-Tree Flowchart for Phytoremediation........................................... 44

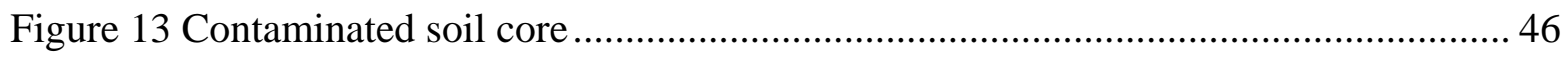

Figure 14 Site characterization of contaminated soil.................................................... 48

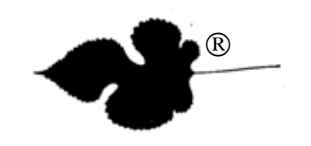




\section{List of Tables}

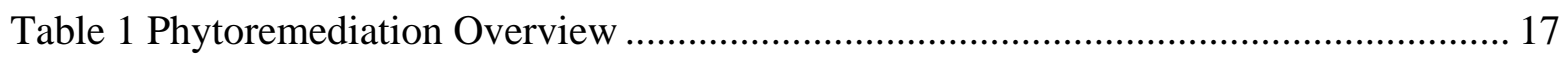

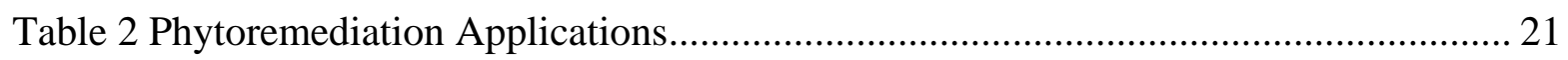

Table 3 Phytoremediation Technologies Applicable to Different Contaminant Types......... 22

Table 4 Summary of Phytoremediation Technologies and Method of Contaminant

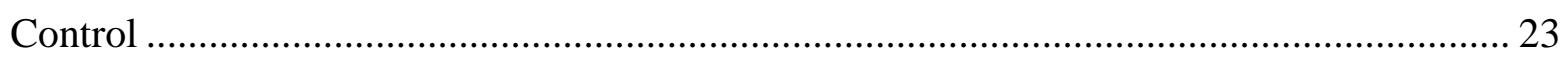

Table 5 Economic Considerations for Phytoremediation .............................................. 25

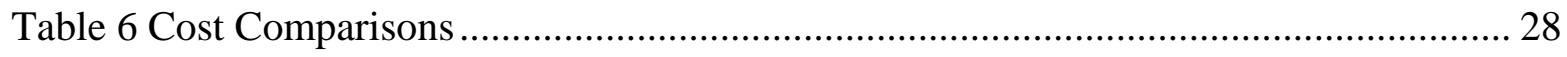

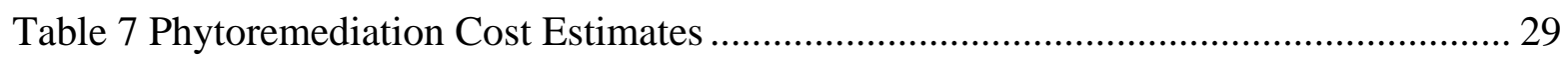




\subsection{Introduction}

Phytoremediation uses plants to degrade, extract, contain, or immobilize contaminants from soil and water. Phytoremediation is an innovative, cost-effective alternative to more conventional treatment methods used in the remediation of hazardous waste sites.

\subsection{Purpose of Decision Guide and Intended Audience}

The purpose of the PhytoRemediate ${ }^{\circledR}$ : Phytoremediation Decision Guide for

Transportation Engineers is to assist transportation engineers and other professionals in the applicability of phytoremediation as an effective method of remediation engineering design. This guide is not a design manual, but identifies the decision-making processes necessary for successful remediation of contaminated sites using phytoremediation.

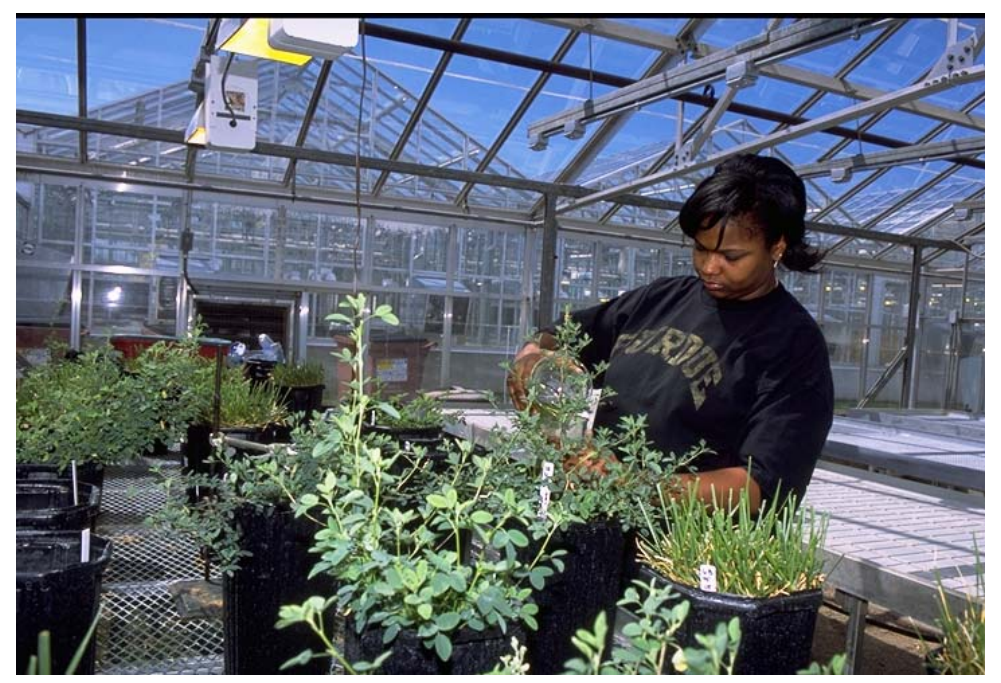

Figure 1. Many plants have been used for the phytoremediation of PAHs and PCBs.

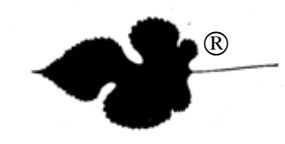

PhytoRemediate ${ }^{\circledR}$ : Phytoremediation Decision Guide for (C2004 Purdue University Transportation Engineers 


\subsection{Objectives of Decision Guide}

The objectives of PhytoRemediate ${ }^{\circledR}$ : Phytoremediation Decision Guide for Transportation Engineers are to:

- Provide a decision guide for transportation engineers to evaluate the applicability of phytoremediation to contaminated sites. Phytoremediation projects have been proposed or applied to ecosystem restoration and soil, surface water, groundwater, and sediment remediation. This decision guide identifies and defines phytoremediation technologies, and provides examples of current research and case studies to aid in the evaluation of proposed phytoremediation applications.

- Develop a decision guide that is accessible for the Indiana Department of Transportation (INDOT) and the Indiana Department of Environmental Management (IDEM) teams and others to evaluate alternative remediation technologies.

- Present phytoremediation system characteristics that transportation engineers and other professionals need to assess the potential applicability of phytoremediation to specific contaminated sites.

- Present a summary of select case studies and their applicability to environmental problems identified by the Indiana Department of Transportation (INDOT), illustrating actual field applications of phytoremediation.

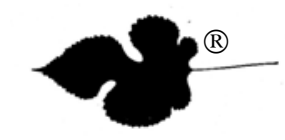




\subsection{Background of Phytoremediation}

Phytoremediation consists of the technologies that use plants to clean up contaminated sites. The term phytoremediation ("phyto" = plant and "remediation" = correct evil) is relatively new. Phytoremediation originated in a number of research areas including constructed wetlands and agricultural applications.

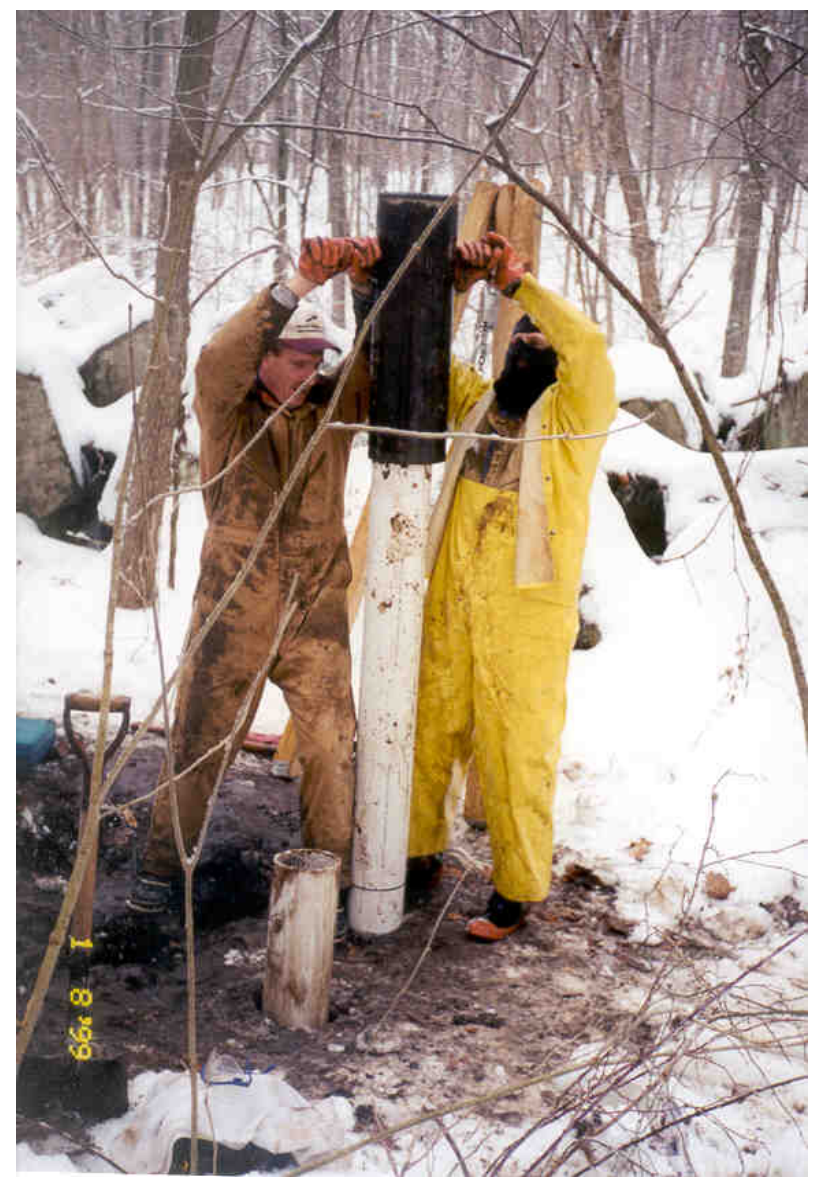

Figure 2. Soil sampling for site characterization for phytoremediation site clean-up in Bedford, Indiana.

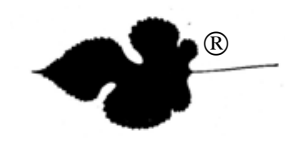

PhytoRemediate $^{\circledR}$ : Phytoremediation Decision Guide for (C)2004 Purdue University

\section{Transportation Engineers}




\subsection{What is Phytoremediation?}

According to McCutcheon and Schnoor (2003), "phytoremediation involves the use of vascular plants, algae, and fungi either to remove and control wastes or to spur waste breakdown by microorganisms in the rhizosphere.” An integral part of phytoremediation is the use of plants to promote microbial degradation or biotransformation of contaminants through the process of rhizodegradation. Phytoremediation is also low-cost, especially when compared to many of the traditional or conventional approaches for hazardous waste management. Vascular green plants have the ability to self-engineer or exert limited control over the plant rhizosphere, rhizosphere biogeochemistry, availability of water and plant nutrients, as well as the local microclimate. Mitsch and Jørgensen (2004) define self-engineering or self-design as "the application of self-organization in the design of ecosystems.”

The hazardous wastes that can be treated using phytoremediation are actually quite diverse, including metals, metalloids, munitions, nonmetals, surfactants, radionuclides, salts, nutrients, xenobiotic organic chemicals (compounds that are foreign to living organisms), sewage, and air pollutants. Some of these xenobiotic organic chemicals include polycyclic aromatic hydrocarbons (PAHs), polychlorinated biphenyls (PCBs) pesticides, pentachlorophenol (PCP), and petroleum hydrocarbons. Phytoremediation also can be used for hydrologic control.

The mechanisms in phytoremediation can include the biotransformation of xenobiotic organic chemicals; degradation of inorganic compounds such as perchlorate and cyanide; and the use of evapotranspiration as a hydrologic control of hazardous wastes in soil, sediments, groundwater, and surface water. Phytoremediation uses green plants to accumulate metals, metalloids, and radionuclides and to stabilize metals and organic pollutants in the environment.

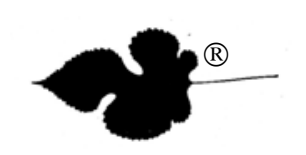

PhytoRemediate $^{\circledR}$ : Phytoremediation Decision Guide for (C)2004 Purdue University Transportation Engineers 


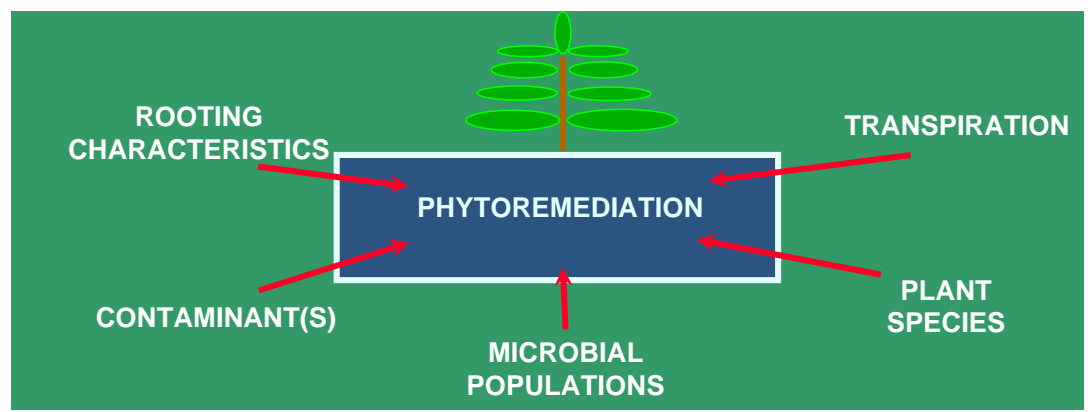

Figure 3. Phytoremediation Processes

\subsection{Brief History of Phytoremediation}

The history of phytoremediation is fairly recent (McCutcheon and Schnoor, 2003). Raskin et al. (1994) were reportedly the first to use the term phytoremediation in a 1991 proposal funded by the U.S. Environmental Protection Agency. Cunningham and Berti (1993) were the first to use the term phytoremediation in the open technical literature, although they noted that the use of green plants for wastewater treatment has occurred for over 300 years. Recently, there have been many applications of phytoremediation in natural and constructed treatment wetlands, and in air pollution control in ambient and indoor air. According to Cunningham and Lee (1995), in the 1970s, plant-based remediation of metals-contaminated soil and dredge material slurries was thoroughly investigated. Cunningham et al. (1996) asserted that matrix toxicity from contaminants may have limited these applications until research on hyperaccumulation was published by Brooks (1998). Alternative methods to manage phytotoxicity were established by several pioneers in phytoremediation (Chaney, 1983; Cunningham and Berti, 1993; U.S. DOE, 1994; Raskin et al., 1994; Baker et al., 1995; Dushenkov et al., 1995; Kumar et al., 1995; McCutcheon et al., 1995; Salt et al., 1995; and Schnoor et al., 1995b.).

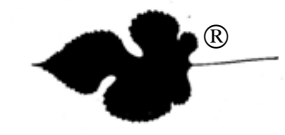

PhytoRemediate $^{\circledR}$ : Phytoremediation Decision Guide for (C)2004 Purdue University Transportation Engineers 


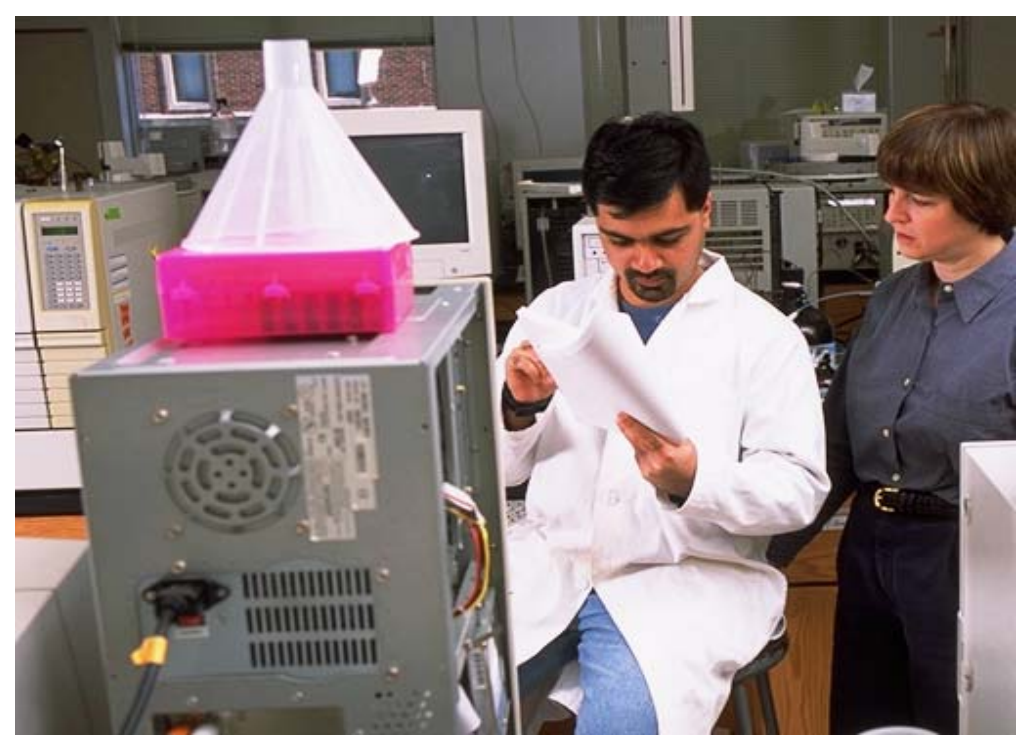

Figure 4. Phytoremediation pioneer Kathy Banks and student in the laboratory.

\subsection{Basic Types of Phytoremediation: Processes and Mechanisms}

There are several basic types of phytoremediation. The following phytoremediation technologies utilize several different processes and mechanisms. These are discussed as follows (McCutcheon and Schnoor, 2003):

- Phytoextraction is the use of plants to uptake contaminants and assimilate them into biomass. Chemicals are taken up from soil with water, by cation pumps, absorption, and translocation aboveground. Shoots and roots are harvested and then disposed in a landfill or smelted following volume reduction by incineration or composting. Hyperaccumulation of metals such as nickel is an example of phytoextraction.

- Phytostabilization is the use of plants to prevent the migration of contaminants through control of the hydraulic gradient or by reinforcing the soil structure. Phytostabilization is 1 ) revegetation to prevent soil erosion and sorbed pollutant transport, 2) use of plants to control $\mathrm{pH}$, soil gases, and sorption to form stable

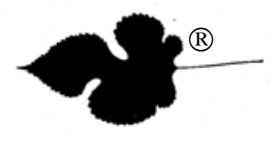

PhytoRemediate $^{\circledR}$ : Phytoremediation Decision Guide for (C)2004 Purdue University Transportation Engineers 
mineral deposits, and 3) humification, lignification, and covalent or irreversible binding of some organic compounds through the action of plant roots.

- Rhizosphere Bioremediation/Rhizodegradation is the use of plant roots to sorb contaminants. Chemicals exuded or secreted from plant roots (root exudates) may also enhance rhizofiltration. It uses the following processes: plant root exudation, root necrosis, and processes supply organic carbon and nutrients to promote soil bacterial growth; stimulate enzyme induction and cometabolic degradation by mycorrhizal fungi and rhizo-microbial consortium; provide diverse rhizosphere habitat; and attenuate chemical transport and concentrations. Live roots also pump oxygen to anaerobes or leave aeration channels.

- Phytodegradation/Phytotransformation is the biochemical process that involves the uptake and metabolism of contaminants by plants. Aquatic and terrestrial plants take up, store, and biodegrade or biotransform xenobiotics to harmless byproducts, products used to create new plant biomass, or by-products that are degraded by microorganisms and other processes to less harmful compounds. Growth and senescence enzymes are a part of plant metabolism, assimilation, or detoxification. Reductive and oxidation enzymes may be operative in different parts of the plant.

- Phytovolatilization is the process whereby volatile metals, metalloids, and organic compounds are taken up into the plant, re-speciated, and transpired. This process involves the uptake and metabolism of contaminants and the subsequent release by the plants into the atmosphere. Some xenobiotics are more easily degraded in the atmosphere.

- Rhizofiltration is the process whereby compounds are taken up, sorbed, or precipitated by roots.

- Hydrologic Control/Plume Control/Phytocontainment is the process whereby plants transpire large quantities of water which may contain shallow groundwater

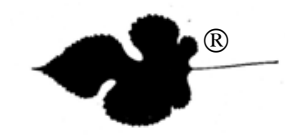

PhytoRemediate $^{\circledR}$ : Phytoremediation Decision Guide for C2004 Purdue University Transportation Engineers 
plumes or contaminated soil leaching by reversing horizontal aquifer hydrologic gradient or vertical soil moisture pressure gradient.

- Riparian Corridors/Buffer Strips use plants as a filter or barrier. They are used as vegetative cover or phytostabilization in the region around rivers, streams, lakes, and wetlands. These areas function as a buffer between these aquatic areas and the adjacent uplands.

- Vegetative Cover can be used for soil erosion control and soil stabilization.

An overview of phytoremediation is shown in Figure 3 and Table 1. Figure 3 summarizes the basic mechanisms in phytoremediation, whereas Table 1 summarizes these mechanisms with process goals, contaminant media, pollutants/contaminants, the plants used with established successes, and the status of the phytoremediation techniques.

\subsubsection{Phytodegradation}

Plants may enhance the biodegradation in the rhizosphere or the zone of influence around the plant roots. Another possible mechanism for contaminant biodegradation is metabolism within the plant. Some plants may be able to take in toxic compounds and detoxify them (USEPA, 2000).

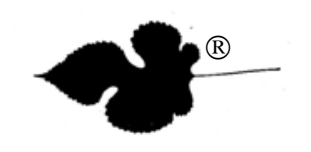


Table 1. Phytoremediation Overview

\begin{tabular}{|c|c|c|c|c|c|}
\hline Mechanism & Process Goal & Media & Contaminants & Plants & Status \\
\hline Phytoextraction & $\begin{array}{l}\text { Contaminant } \\
\text { extraction and } \\
\text { capture }\end{array}$ & $\begin{array}{l}\text { Soil, sediment, } \\
\text { sludges }\end{array}$ & $\begin{array}{l}\text { Metals: Ag, Cd, } \\
\mathrm{Co}, \mathrm{Cr}, \mathrm{Cu}, \mathrm{Hg}, \\
\mathrm{Mn}, \mathrm{Mo}, \mathrm{Ni}, \mathrm{Pb} \text {, } \\
\text { Zn; Radionuclides: } \\
{ }^{90} \mathrm{Sr},{ }^{137} \mathrm{Cs},{ }^{239} \mathrm{Pu}, \\
{ }^{238,234} \mathrm{U}\end{array}$ & $\begin{array}{l}\text { Indian mustard, } \\
\text { pennycress, } \\
\text { alyssum, } \\
\text { sunflowers, hybrid } \\
\text { poplars }\end{array}$ & $\begin{array}{l}\text { Laboratory, pilot, } \\
\text { and } \\
\text { field applications }\end{array}$ \\
\hline Rhizofiltration & $\begin{array}{l}\text { Contaminant } \\
\text { extraction and } \\
\text { capture }\end{array}$ & $\begin{array}{l}\text { Groundwater, } \\
\text { surface water }\end{array}$ & $\begin{array}{l}\text { Metals, } \\
\text { radionuclides }\end{array}$ & $\begin{array}{l}\text { Sunflowers, Indian } \\
\text { mustard, water } \\
\text { hyacinth }\end{array}$ & $\begin{array}{l}\text { Laboratory and } \\
\text { pilot application }\end{array}$ \\
\hline Phytostabilization & $\begin{array}{l}\text { Contaminant } \\
\text { containment }\end{array}$ & $\begin{array}{l}\text { Soil, sediment, } \\
\text { sludges }\end{array}$ & $\begin{array}{l}\text { As, } \mathrm{Cd}, \mathrm{Cr}, \mathrm{Cu} \text {, } \\
\mathrm{Hs} \text { ???, } \mathrm{Pb}, \mathrm{Zn}\end{array}$ & $\begin{array}{l}\text { Indian mustard, } \\
\text { hybrid poplars, } \\
\text { grasses }\end{array}$ & Field application \\
\hline Rhizodegradation & $\begin{array}{l}\text { Contaminant } \\
\text { destruction }\end{array}$ & $\begin{array}{l}\text { Soil, sediment, } \\
\text { sludges, } \\
\text { groundwater, }\end{array}$ & $\begin{array}{l}\text { Organic } \\
\text { compounds (TPH, } \\
\text { PAHs, pesticides } \\
\text { chlorinated } \\
\text { solvents, PCBs) }\end{array}$ & $\begin{array}{l}\text { Red mulberry, } \\
\text { grasses, hybrid } \\
\text { poplar, cattail, rice }\end{array}$ & Field application \\
\hline Phytodegradation & $\begin{array}{l}\text { Contaminant } \\
\text { destruction }\end{array}$ & $\begin{array}{l}\text { Soil, sediment, } \\
\text { sludges, } \\
\text { groundwater } \\
\text { surface water }\end{array}$ & $\begin{array}{l}\text { Organic } \\
\text { compounds: } \\
\text { chlorinated } \\
\text { solvents, phenols, } \\
\text { herbicides, } \\
\text { munitions }\end{array}$ & $\begin{array}{l}\text { Algae, stonewort, } \\
\text { hybrid poplar, } \\
\text { black willow, bald } \\
\text { cypress }\end{array}$ & $\begin{array}{l}\text { Field } \\
\text { demonstration }\end{array}$ \\
\hline Phytovolatilization & $\begin{array}{l}\text { Contaminant } \\
\text { extraction from } \\
\text { media and release } \\
\text { to air }\end{array}$ & $\begin{array}{l}\text { Groundwater, soil, } \\
\text { sediment, sludges }\end{array}$ & $\begin{array}{l}\text { Chlorinated } \\
\text { solvents, some } \\
\text { inorganics (Se, Hg, } \\
\text { and As) }\end{array}$ & $\begin{array}{l}\text { Poplars, alfalfa } \\
\text { black locust, } \\
\text { Indian mustard }\end{array}$ & $\begin{array}{l}\text { Laboratory and } \\
\text { field application }\end{array}$ \\
\hline $\begin{array}{l}\text { Hydrologic control } \\
\text { (plume control) }\end{array}$ & $\begin{array}{l}\text { Contaminant } \\
\text { degradation or } \\
\text { containment }\end{array}$ & $\begin{array}{l}\text { Groundwater } \\
\text { surface water, }\end{array}$ & $\begin{array}{l}\text { Water-soluble } \\
\text { organics and } \\
\text { inorganics }\end{array}$ & $\begin{array}{l}\text { Hybrid poplar, } \\
\text { cottonwood, } \\
\text { willow }\end{array}$ & $\begin{array}{l}\text { Field } \\
\text { demonstration }\end{array}$ \\
\hline $\begin{array}{l}\text { Vegetative cover } \\
\text { (evapotranspiration } \\
\text { cover) }\end{array}$ & $\begin{array}{l}\text { Contaminant } \\
\text { containment, } \\
\text { erosion control }\end{array}$ & $\begin{array}{l}\text { Soil, sludge, } \\
\text { sediments }\end{array}$ & $\begin{array}{l}\text { Organic and } \\
\text { inorganic } \\
\text { compounds }\end{array}$ & Poplars, grasses & Field application \\
\hline $\begin{array}{l}\text { Riparian corridors } \\
\text { (non-point source } \\
\text { control) }\end{array}$ & $\begin{array}{l}\text { Contaminant } \\
\text { destruction }\end{array}$ & $\begin{array}{l}\text { Surface water, } \\
\text { groundwater }\end{array}$ & $\begin{array}{l}\text { Water-soluble } \\
\text { organics and } \\
\text { inorganics }\end{array}$ & Poplars & Field application \\
\hline
\end{tabular}

Source: USEPA, 2000.

\section{PhytoRemediate $^{\circledR}$ : Phytoremediation Decision Guide for Transportation Engineers}

(C)2004 Purdue University 
Phytodegradation is the breakdown of contaminants taken up by the plant through metabolic processes within the plant, or the breakdown of contamiants external to the plant through the effect of compounds (such as enzymes) produced by the plant.

Physical Effects involve the transpiration of volatiles and hydraulic control of dissolved plume.

\section{Enhanced rhizosphere biodegradation}

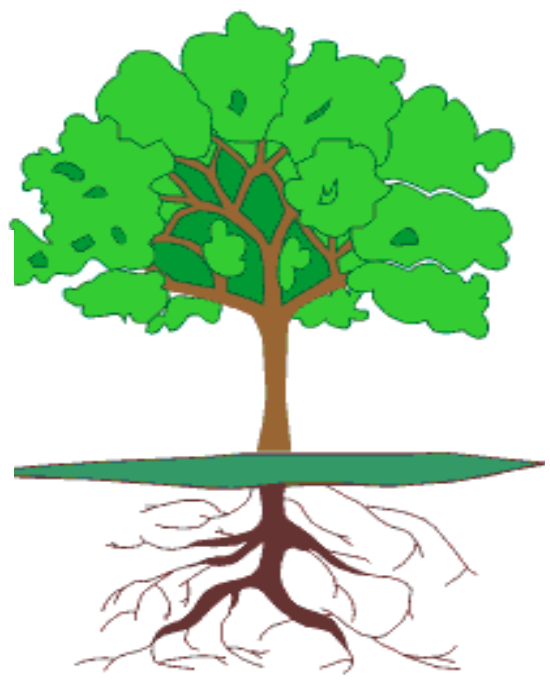

Accumulation in roots translocated to shoots and leaves.

Figure 5. Phytoremediation Mechanisms (modified from USEPA, 2001 and the tree graphic from http://www.cist.org/ay/gm/ga1501.htm)

\subsubsection{Phytoextraction}

Phytoextraction, or phyto-mining, is the process of the accumulation or hyperaccumulation of contaminants in the shoots and leaves of the plants, and then harvesting the plant and removing the contaminant from the site. Unlike the destructive

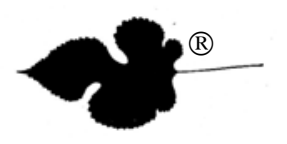

PhytoRemediate ${ }^{\circledR}$ : Phytoremediation Decision Guide for (C2004 Purdue University

\section{Transportation Engineers}


degradation mechanisms, phytoextraction yields of plant biomass with contaminants, typically metals, which must be disposed or recycled.

Rhizofiltration is similar to phytoextraction because it also is a concentration technology. Rhizofiltration differs from phytoextraction because the mechanism is root accumulation and harvest of a contaminant using hydroponic or other aquaculture techniques.

Phytovolatilization, transpiration of volatile contaminants through plants into the atmosphere, is another possible mechanism for removing a contaminant from the soil or groundwater of a site (USEPA, 2000).

\subsubsection{Containment and Immobilization of Contaminants}

Bioavailability is defined by Mitsch and Jørgensen (2004) as the amount of contaminant present that can be taken up readily by organisms. Bioavailability is a critical factor in the application of bioremediation and hence phytoremediation. Containment using plants either enhances sorption of the contaminants to the soil, rendering them nonbioavailable, or immobilizing them relative to physical transport. Environmental and health risk reduction can be accomplished by transforming the contaminant into a form that is not hazardous, or by rendering the contaminant nonbioavailable.

Hydrologic control is another type of containment of contaminants. Groundwater contaminant plume control can be achieved by using plants to increase the evapotranspiration from a site. Some plants use tremendous quantities of water in evapotranspiration, and can extend roots to great depths to draw from the unsaturated zone (vadose zone) and ultimately from the saturated zone (phreatic zone).

Vegetative cover, also evapotranspiration or water-balance cover, systems are another application utilizing the natural mechanisms of plants to minimize infiltrating

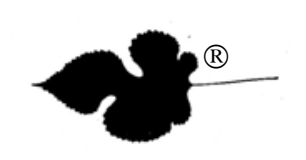

PhytoRemediate $^{\circledR}$ : Phytoremediation Decision Guide for (C)2004 Purdue University Transportation Engineers 
water. If there is potential for gas generation, a vegetative cover may not be an appropriate option (USEPA, 2000).

\subsubsection{Phytoremediation Applications}

A summary of phytoremediation applications is shown in Table 2. These applications are described by the mechanism of phytoremediation, the pollutant or contaminant, the contaminant media, the plant(s) used, the status of the project, and the reference citation.

Table 3 is a summary of phytoremediation technologies applicable to different contaminant types. The technology media, whether used for contaminated soil or water, are phytoextraction, rhizofiltration, phytostabilization, rhizodegradation, phytodegradation, and phytovolatilization. The technology media are chlorinated solvents, metals, metalloids, munitions, nonmetals, nutrients, PAHs, PCBs, PCP, pesticides, petroleum hydrocarbons, radionuclides, and surfactants. This summary of phytoremediation technologies will enable INDOT to make informed decisions and proper engineering design when dealing with specific environmental problems as well as the effectiveness of these phytoremediation technologies.

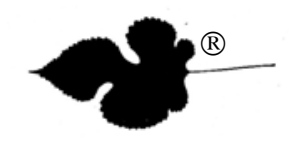


Table 2. Phytoremediation Applications

\begin{tabular}{|c|c|c|c|c|c|}
\hline Mechanism & Contaminant & Media & Plant & Status & Reference \\
\hline Degradation & $\begin{array}{l}\text { Atrazine and } \\
\text { nitrates }\end{array}$ & Surface Water & Poplar & Applied & Schnoor, 1995a \\
\hline Degradation & $\begin{array}{l}\text { Landfill } \\
\text { leachate }\end{array}$ & Groundwater & Poplar & Applied & Licht, 1990 \\
\hline Degradation & TCE & Groundwater & $\begin{array}{l}\text { Poplar and } \\
\text { cottonwood }\end{array}$ & $\begin{array}{l}\text { Field } \\
\text { demonstration }\end{array}$ & Rock, 1997 \\
\hline Degradation & TNT & Wetlands & Various plants & $\begin{array}{l}\text { Field } \\
\text { demonstration }\end{array}$ & $\begin{array}{l}\text { Bader, } 1996 \\
\text { Carreira, } 1996 \\
\text { McCutcheon, } \\
1995\end{array}$ \\
\hline Degradation & TPH & Soil & $\begin{array}{l}\text { Grasses and } \\
\text { crops }\end{array}$ & $\begin{array}{l}\text { Field } \\
\text { demonstration }\end{array}$ & $\begin{array}{l}\text { Banks et al., } \\
1997 \\
\text { Drake, } 1997\end{array}$ \\
\hline $\begin{array}{l}\text { Extraction- } \\
\text { Concentration } \\
\text { in shoot }\end{array}$ & Lead & Soil & Indian mustard & $\begin{array}{l}\text { Field } \\
\text { demonstration }\end{array}$ & $\begin{array}{l}\text { Blaylock et al., } \\
1997\end{array}$ \\
\hline $\begin{array}{l}\text { Extraction- } \\
\text { Concentration } \\
\text { in root }\end{array}$ & Uranium & Surface water & Sunflower & $\begin{array}{l}\text { Field } \\
\text { demonstration }\end{array}$ & $\begin{array}{l}\text { Dushenkov et } \\
\text { al., } 1997\end{array}$ \\
\hline $\begin{array}{l}\text { Extraction, } \\
\text { Volatilization }\end{array}$ & Selenium & $\begin{array}{l}\text { Soil and } \\
\text { Surface Water }\end{array}$ & Various plants & Applied & $\begin{array}{l}\text { Bañuelos, } 1996 \\
\text { Terry, } 1996\end{array}$ \\
\hline
\end{tabular}

Source: USEPA, 2000. 
Table 3. Phytoremediation Technologies Applicable to Different Contaminant Types ${ }^{1,2}$

\begin{tabular}{|c|c|c|c|c|c|c|c|c|c|}
\hline \multirow{2}{*}{ Technology Media } & \multicolumn{2}{|c|}{ Phytoextraction } & \multirow{2}{*}{$\begin{array}{c}\text { Rhizofiltration } \\
\text { Soil }\end{array}$} & \multirow{2}{*}{$\begin{array}{c}\text { Phytostabilization } \\
\text { Soil }\end{array}$} & \multirow{2}{*}{$\begin{array}{c}\text { Rhizodegradation } \\
\text { Soil }\end{array}$} & \multicolumn{2}{|c|}{ Phytodegradation } & \multicolumn{2}{|c|}{ Phytovolatilization } \\
\hline & Soil & Water & & & & Soil & Water & Soil & Water \\
\hline Chlorinated solvents & $\mathrm{F}$ & $\mathrm{F}$ & & & $\mathrm{F}$ & $\mathrm{F}$ & $\mathrm{F}$ & $\mathrm{F}$ & $\mathrm{F}$ \\
\hline Metals $^{3}$ & $\mathrm{~F}$ & $\mathrm{~F}$ & F & $\mathrm{F}$ & & & & $\mathrm{G}(\mathrm{Hg})$ & \\
\hline Metalloids & G & $\mathrm{F}(\mathrm{Se})$ & & $\mathrm{T}$ & & & & G & $\mathrm{F}(\mathrm{Se})$ \\
\hline Munitions & & & & & G & G & $\mathrm{F}$ & & \\
\hline Nonmetals & G & G & & & $\mathrm{F}$ & & & & \\
\hline Nutrients & $\mathrm{F}$ & $\mathrm{F}$ & $\mathrm{F}^{5}$ & & G & $\mathrm{F}$ & $\mathrm{F}$ & & \\
\hline PAHs & & & & & $\mathrm{F}$ & & & & \\
\hline PCBs & G & G & & & $\mathrm{F}$ & G & G & & \\
\hline РСР & & & & G & $\mathrm{F}$ & & & & \\
\hline Pesticides & $\mathrm{F}$ & $\mathrm{F}$ & & & $\mathrm{F}$ & F & $\mathrm{F}$ & $\mathrm{T}$ & \\
\hline $\begin{array}{l}\text { Petroleum } \\
\text { hydrocarbons }\end{array}$ & $\mathrm{T}$ & & & & $\mathrm{F}$ & $\mathrm{F}$ & $\mathrm{F}$ & $\mathrm{T}$ & \\
\hline Radionuclides ${ }^{4}$ & G & F & $\mathrm{F}$ & G & & & & & \\
\hline Surfactants & & & & & $\mathrm{T}$ & & & & \\
\hline
\end{tabular}

${ }^{1}$ The applicability of a particular method of phytoremediation to each contaminant type has been judged by the current state or stage of the application.

This is indicated in the table by the following designations:

$\mathrm{T}$ - The application is at the theoretical stage.

$\mathrm{G}$ - The application has been researched in the greenhouse or laboratory.

$\mathrm{F}$ - The application has been researched using field plots or has been applied in full-scale field systems.

${ }^{2}$ All contaminants can be controlled using vegetative covers. The vegetative cover, riparian corridors, buffer strips, and hydrologic control are not included in the table because they can be considered combinations of the other phytoremediation technologies.

${ }^{3}$ Reeves and Brooks 1983; Baker et al., 1995, Salt et al. 1995; Nanda Kumar et al. 1995; Cornish et al. 1995.

${ }^{4}$ Salt et al. 1995; Nanda Kumar et al. 1995; Cornish et al. 1995.

${ }^{5}$ In constructed wetlands.

Source: USEPA, 2000.

Table 4 summarizes phytoremediation technologies and the methods of contaminant

control. Emphasis is placed on whether the contaminant is destroyed through

biotransformation, extracted or taken up into the plant, or contained using vegetative cover or riparian corridors.

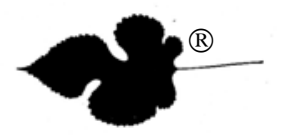

PhytoRemediate $^{\circledR}$ : Phytoremediation Decision Guide for

(C)2004 Purdue University

\section{Transportation Engineers}


Table 4. Summary of Phytoremediation Technologies and Method of Contaminant Control

\begin{tabular}{|c|c|c|c|}
\hline Method & Destruction & Extraction/Uptake & Containment \\
\hline $\begin{array}{l}\text { Phytoextraction } \\
\text { (concentration) }\end{array}$ & & * & \\
\hline Rhizofiltration & & * & \\
\hline Phytostabilization & & $*$ & \\
\hline Rhizodegradation & $*$ & & \\
\hline Phytodegradation & $*$ & & \\
\hline Phytovolatilization & & * & \\
\hline Plume control & & & \\
\hline Vegetative cover & $*^{\mathrm{a}}$ & & $*^{\mathrm{b}}$ \\
\hline Riparian corridors & $*$ & * & * \\
\hline
\end{tabular}

a Phytoremediation cover.

b Evapotranspiration cover .

Source: USEPA, 2000.

\subsection{Technical Considerations for Phytoremediation}

According to USEPA (2000), several key issues should be considered when evaluating whether phytoremediation is a potential solution or design mechanism to clean up contaminated sites. Some of the key issues are as follows:

1. Determine whether phytoremediation will effectively remove target contaminants. Laboratory studies on properly selected plants and the site contaminants may be necessary to support the use of phytoremediation at a particular site. These pilot studies will show if the plants to be used at the site are capable of remediation before the implementation of field-scale phytoremediation.

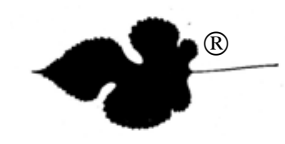

PhytoRemediate $^{\circledR}$ : Phytoremediation Decision Guide for (C)2004 Purdue University Transportation Engineers 
2. Consider the effectiveness of the remediation technique over the time required for plant establishment.

3. Consider if phytoremediation is likely to clean-up the site in an acceptable time frame. (what is the difference between 2 and 3)??

4. Identify adequate backup or contingency plan if phytoremediation is attempted and does not succeed. The monitoring of the efficacy of any innovative treatment such as phytoremediation may be more extensive or expensive than would be required when using traditional technologies. The monitoring should address both the decrease in concentration of the contaminants in the media of concern (contaminant reduction) as well as examine the fate and transport mechanisms of the contaminants. The monitoring plan must be suited to the site.

\subsection{Economic Considerations for Phytoremediation}

Because phytoremediation is a relatively new and emerging technology, reliable cost information is not readily available. As a result, the ability to develop cost comparisons needs to be assessed on a site-specific basis. Two considerations that influence the economics of phytoremediation are: 1) the potential for the application and 2) the cost comparison to conventional treatments. Care must be taken to compare whole system costs, which may include the design costs, operating cost, and monitoring needs that are summarized in Table 5 (USEPA, 2000).

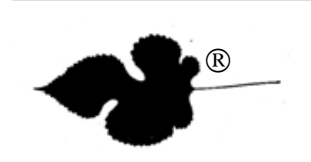


Table 5. Economic Considerations for Phytoremediation

\begin{tabular}{|c|c|c|c|}
\hline \multicolumn{2}{|c|}{ 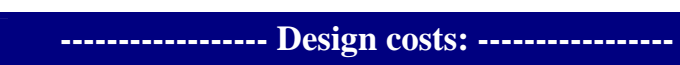 } & \multirow{2}{*}{$\begin{array}{l}\text { Operating costs: } \\
\text { Maintenance }\end{array}$} & \multirow{2}{*}{$\begin{array}{l}\text { Monitoring: } \\
\text { Soil nutrient }\end{array}$} \\
\hline Site characterization & Chelating agents & & \\
\hline $\begin{array}{l}\text { Work plan and report } \\
\text { preparation }\end{array}$ & $\mathrm{pH}$ control & Irrigation water & Soil pH \\
\hline $\begin{array}{l}\text { Treatability and pilot } \\
\text { testing }\end{array}$ & Drainage & Fertilizer & Soil water \\
\hline Installation costs & Infrastructure & pH control & Plant nutrient status \\
\hline Site preparation & Irrigation system & Chelating agent & $\begin{array}{l}\text { Plant contaminant status } \\
\text { (roots, shoots, stems, } \\
\text { leaves) }\end{array}$ \\
\hline Facilities removal & Fencing & Drainage water disposal & Tree sap flow monitoring \\
\hline Debris removal & Planting & Pesticides & Air monitoring \\
\hline $\begin{array}{l}\text { Utility line } \\
\text { removal/relocation }\end{array}$ & Seeds, plants & Fencing/pest control & Weather monitoring \\
\hline Soil preparation & Labor & Replanting & \\
\hline $\begin{array}{l}\text { Physical modification: } \\
\text { tilling }\end{array}$ & Protection & & \\
\hline
\end{tabular}

Source: USEPA, 2000

The following discussion describes cost estimates for phytoremediation (USEPA, 2000 and Glass, 2000). Cost comparisons are also shown in Tables 6 and 7.

\subsubsection{Phytoextraction Costs}

Phytoextraction uses plants that are known to accumulate contaminants in the shoots and leaves of these plants, and subsequently harvesting the plant and removing the contaminant from the site. Example phytoextraction costs are as follows:

1. The estimated 30-year costs (1998 dollars) for the remediation of a 12-acre site contaminated with lead were $\$ 12,000,000$ for excavation and disposal;

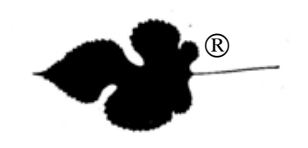

PhytoRemediate $^{\circledR}$ : Phytoremediation Decision Guide for

(C)2004 Purdue University Transportation Engineers 
$\$ 6,300,000$ for soil washing; $\$ 600,000$ for the construction of a soil cap; and \$200,000 for phytoextraction (Cunningham et al., 1996).

2. Cost estimates made for remediation of a hypothetical case of a 20-in.-thick layer of sediments contaminated with $\mathrm{Cd}, \mathrm{Zn}$, and ${ }^{137} \mathrm{Cs}$ from a 1.2-acre chemical waste disposal pond indicated that phytoextraction would cost about one-third the amount of soil washing (Cornish et al., 1995).

3. Costs were estimated to be $\$ 60,000$ to $\$ 100,000$ using phytoextraction for the remediation of a one acre site that consisted of a 20-inch thick sandy loam compared to a minimum of $\$ 400,000$ for just the excavation and storage of this soil (Salt et al., 1995).

\subsubsection{Rhizofiltration Costs}

Rhizofiltration is a concentration technology where the mechanism is root accumulation and harvest of the contaminant in the roots. The cost of removing radionuclides from water with sunflowers has been estimated to be $\$ 2$ to $\$ 6$ per thousand gallons of water (Dushenkov et al. 1997).

\subsubsection{Phytostabilization Costs}

Phytostabilization uses plants to prevent the migration of contaminants by controlling the hydrologic gradient or by reinforcing the soil structure. A cropping system used as a phytostabilization technique has been estimated at $\$ 200$ to $\$ 10,000$ per hectare, equivalent to $\$ 0.02$ to $\$ 1.00$ per cubic meter of soil, assuming a 1-meter root depth (Cunningham et al. 1995b).

\subsubsection{Hydrologic Control Costs}

Hydrologic control or the use of plants to move water from the contaminated sediments by evapotranspiration is quite effective. Estimated costs for remediation of an

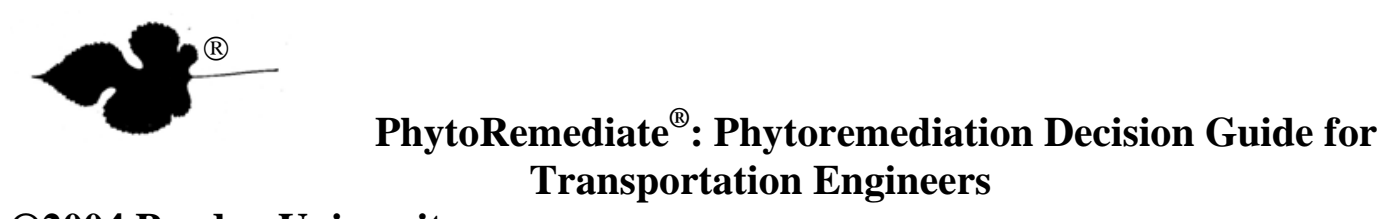

(C)2004 Purdue University

\section{Transportation Engineers}


unspecified contaminant in a 20 -foot-deep aquifer at a 1 -acre site were $\$ 660,000$ for conventional pump-and-treat, and \$250,000 for phytoremediation using trees for groundwater control (Gatliff, 1994).

\subsubsection{Vegetative Cover Costs}

Vegetative cover for soil erosion and sediment control, and soil stabilization is also an effective phytoremediation technique. Cost estimates indicate savings for an evapotranspiration cover compared to a traditional cover design to be 20 to $50 \%$, depending on availability of suitable soil for the plant growth medium used for vegetative cover (RTDF, 1998).

\subsubsection{Rhizodegradation}

Rhizodegradation is also an effective phytoremediation technique. Cost estimates indicate a projected savings of $80 \%$ using rhizodegradation when compared to conventional treatment. Total petroleum hydrocarbons (TPH) can be removed using this in situ phytoremediation application (USEPA, 2000).

\subsubsection{Phytoremediation cost comparisons and estimates}

A summary of cost comparisons is shown in Tables 6 and 7. These cost comparisons are identified by specific case studies or problems, the basic phytoremediation applications used, and costs as compared to conventional treatments. The projected savings are also summarized.

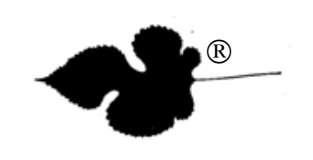


Table 6. Cost Comparisons

\begin{tabular}{|llllll|}
\hline Problem & $\begin{array}{l}\text { Phytoremediation } \\
\text { Application }\end{array}$ & $\begin{array}{l}\text { Cost } \\
\text { (\$ thousand) }\end{array}$ & $\begin{array}{l}\text { Conventional } \\
\text { Treatment }\end{array}$ & $\begin{array}{l}\text { Cost } \\
\text { (\$ thousand) }\end{array}$ & $\begin{array}{l}\text { Projected } \\
\text { Savings }\end{array}$ \\
\hline $\begin{array}{l}\text { Lead in soil, } \\
1 \text { acre }^{\mathrm{a}}\end{array}$ & $\begin{array}{l}\text { Extraction, } \\
\text { harvest disposal }\end{array}$ & $\$ 150-250$ & $\begin{array}{l}\text { Excavate and } \\
\text { landfill }\end{array}$ & $\$ 500$ & $50-65 \%$ \\
$\begin{array}{l}\text { Solvents in } \\
\text { groundwater, } \\
2.5 \text { acres }^{\mathrm{b}}\end{array}$ & $\begin{array}{l}\text { Degradation and } \\
\text { hydrologic control }\end{array}$ & $\begin{array}{l}\$ 200 \\
\text { installation } \\
\text { and initial } \\
\text { maintenance }\end{array}$ & Pump and treat & $\begin{array}{l}\text { \$700 annual } \\
\text { running cost }\end{array}$ & $\begin{array}{l}\text { 50\% cost } \\
\text { saving by } \\
\text { third year }\end{array}$ \\
$\begin{array}{l}\text { TPH in soil, } \\
1 \text { acre }^{\mathrm{c}}\end{array}$ & In situ degradation & $\$ 50-100$ & $\begin{array}{l}\text { Excavate and } \\
\text { landfill } \\
\text { incinerate }\end{array}$ & $\$ 500$ & $80 \%$ \\
\hline
\end{tabular}

Source: USEPA, 2000.

${ }^{a}$ Phytotech estimate for Magic Marker site (Blaylock et al. 1997).

${ }^{\mathrm{b}}$ PRP estimate for Solvent Recovery Systems of New England site (USEPA, 2000).

${ }^{\mathrm{c}}$ PERF estimate (Drake, 1997).

\subsection{Environmental Problems Identified by the Indiana Department of Transportation (INDOT)}

The Indiana Department of Transportation (INDOT) may encounter environmental problems as a result of accidental spills and disposal of hazardous materials, construction and maintenance of roads, and the salting of roads. Potential contaminants include solvents and petroleum, heavy metals in soils from paint disposal, excessive soil salinity that restricts plant growth and makes the soil susceptible to erosion, and road construction resulting in disturbance to natural wetlands and destruction of roadside vegetation leading to soil erosion.

According to the information obtained from the Environmental Services Section of INDOT, the main environmental problems leading to remediation and reclamation are presented below followed by a brief discussion.

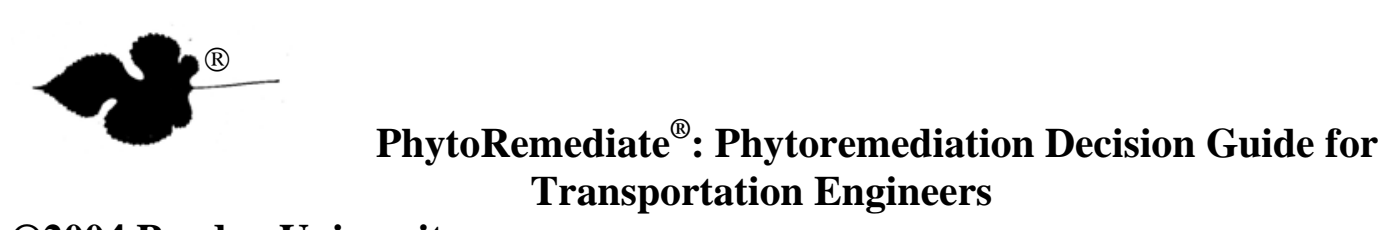

(C)2004 Purdue University 
Table 7. Phytoremediation Cost Estimates

\begin{tabular}{|c|c|c|}
\hline Contaminant Media & Estimated Costs & Source \\
\hline Soil & \$1-10/cubic meter & $\begin{array}{l}\text { Cunningham et al., 1996, } \\
\text { (DuPont) }\end{array}$ \\
\hline Soil & \$10/cubic yard & $\begin{array}{l}\text { Glass, } 2000 \text { (Geraghty \& } \\
\text { Miller) }\end{array}$ \\
\hline Soil & $\$ 15-20 /$ ton & Drake, 1997 (Exxon) \\
\hline Soil & $\$ 25-50 /$ ton & $\begin{array}{l}\text { Blaylock et al. } 1997 \\
\text { (Phytotech) }\end{array}$ \\
\hline Soil & $\$ 29-48 /$ cubic meter & Salt et al., 1995 \\
\hline Soil & \$80/cubic yard & $\begin{array}{l}\text { Glass, 2000(R. Levine, } \\
\text { DOE) }\end{array}$ \\
\hline Soil & \$96/cubic yard & $\begin{array}{l}\text { Glass, } 2000 \text { (Jerger et al. IT } \\
\text { Corporation) }\end{array}$ \\
\hline Soil & $\$ 100-150 /$ cubic meter & $\begin{array}{l}\text { Glass, 2000(R. Chaney, } \\
\text { USDA) }\end{array}$ \\
\hline $\begin{array}{l}\text { Water } \\
\text { (per } 1,000 \text { gallons treated) }\end{array}$ & $\$ 0.64$ & $\begin{array}{l}\text { Glass, 2000(V. Medina, } \\
\text { EPA) }\end{array}$ \\
\hline $\begin{array}{l}\text { Water } \\
\text { (per } 1,000 \text { gallons treated) }\end{array}$ & $\$ 2.00-6.00$ & $\begin{array}{l}\text { Blaylock et al. } 1997 \\
\text { (Phytotech) }\end{array}$ \\
\hline $\begin{array}{l}\text { Vegetative Cover } \\
\text { (e.g. Landfill Cap, } \\
\text { Wastewater }\end{array}$ & $\$ 10-20,000 /$ acre & $\begin{array}{l}\text { Glass, } 2000 \text { (Christensen- } \\
\text { Kirsh 1996, citing CH2M } \\
\text { Hill data) }\end{array}$ \\
\hline $\begin{array}{l}\text { Vegetative Cover } \\
\text { (e.g. Landfill Cap, } \\
\text { Wastewater) }\end{array}$ & $\$ 14-30,000 /$ acre & $\begin{array}{l}\text { Glass, } 2000 \text { (EPA RTDF } \\
\text { Action Team) }\end{array}$ \\
\hline
\end{tabular}

Source: Glass, 2000 
Underground Storage Tanks (USTs): USTs with leaking petroleum products resulting in soil contamination are one of the foremost environmental problems encountered by INDOT. These USTs are located on the properties acquired by INDOT for road construction and facility development. On an average, INDOT undertakes several such projects a year and most address several USTs with environmental impact. At present, the remedial approach followed by INDOT is to remove the tank, and the contaminated soil, and transport both to a landfill for disposal. This is the least expensive option for INDOT. However, INDOT does encounter some petroleum contamination of soil on associated properties due to the violation of right-of-way. Such problems are due to intrusion of INDOT property soils by contaminant plumes as a result of other responsible parties. Under these circumstances, INDOT does use bioremediation technology for clean-up.

Lead Contamination: Contamination of soils by lead due to the past use of lead-based paints on road bridges is one of the most serious problems faced by INDOT. There are several lead contaminated sites throughout Indiana. 


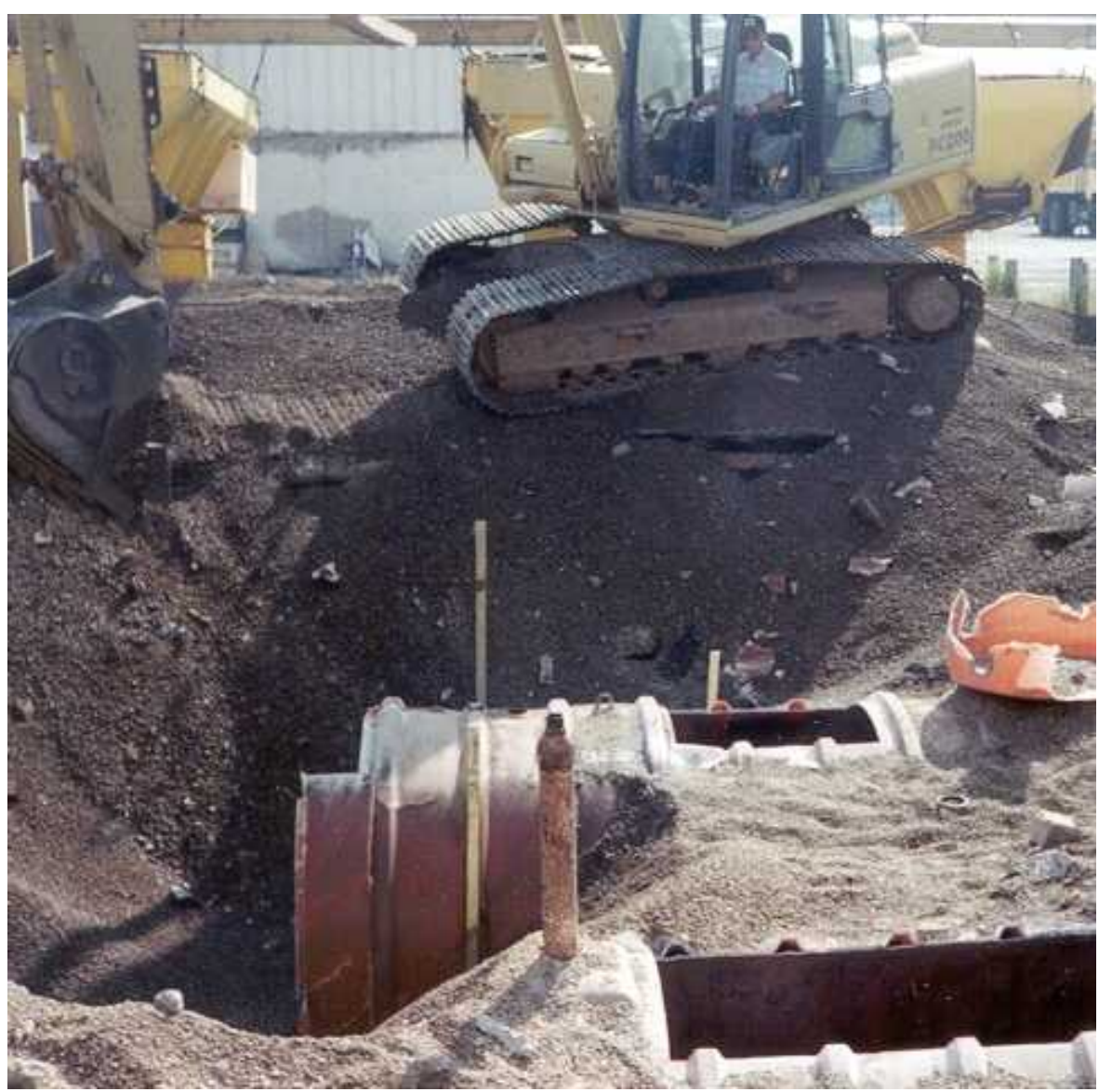

Figure 6. Excavator removing an underground storage tank

(source: http://www.in.gov/dot/programs/environment/images/TankYank.jpg)

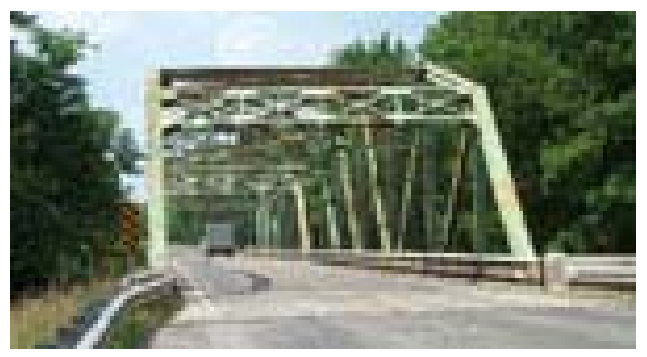

Figure 7. Many INDOT bridges have been painted with lead-based paint. (Source: http://www.in.gov/dot/div/envassess/bridges/br7c2.html)

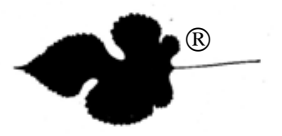

PhytoRemediate $^{\circledR}$ : Phytoremediation Decision Guide for Transportation Engineers 
Hazardous materials spills: Hazardous materials spills are not very common for INDOT sites. These spills occur sporadically and the information about the spill is reported directly to Indiana Department of Environmental Management (IDEM). Subsequently, INDOT identifies the responsible parties and determines the required cleanup in coordination with IDEM. However, INDOT is faced with a dilemma when they are not able to identify or locate the responsible parties. In this case, INDOT incurs the cost of cleanup. The exact number of these incidents is unknown.

Deicing salts: Surface water run-off from highways and storage of deicing salts result in potential environmental problems for INDOT. Highway run-off water laden with deicing salts has a maximum impact on soils and receiving water bodies during spring. This impact is negligible in summer and in fall is non-existent. However, the main environmental concern from INDOT's point of view is the run-off resulting from the uncovered salt storage at a few sites in the state.

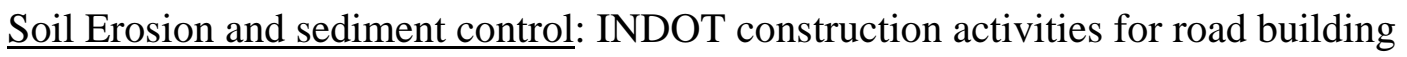
results in soil erosion. Soil erosion and sediment control measures are undertaken by INDOT by hiring contractors who reclaim impacted soils. One option is the use of vegetation to stabilize impacted soils. INDOT receives at least five or six noncompliance notices for soil erosion and sediment control problems per year. Identifying the sites requiring soil erosion and sediment control, and implementing plant stabilization is seen as the least expensive option.

Apart from the above mentioned problems, INDOT also faces other environmental issues such as the mitigation of impacted natural wetlands and the existence of roadside landfills. Natural wetlands are impacted because of construction activities of INDOT. Regulations require INDOT to mitigate any impacts on wetlands through restoration of the impacted area. INDOT also has encountered problems resulting from the roadside landfills that are present on the properties acquired for their

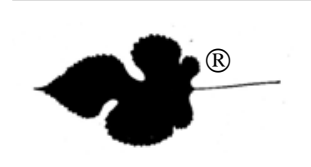

PhytoRemediate $^{\circledR}$ : Phytoremediation Decision Guide for (C)2004 Purdue University Transportation Engineers 


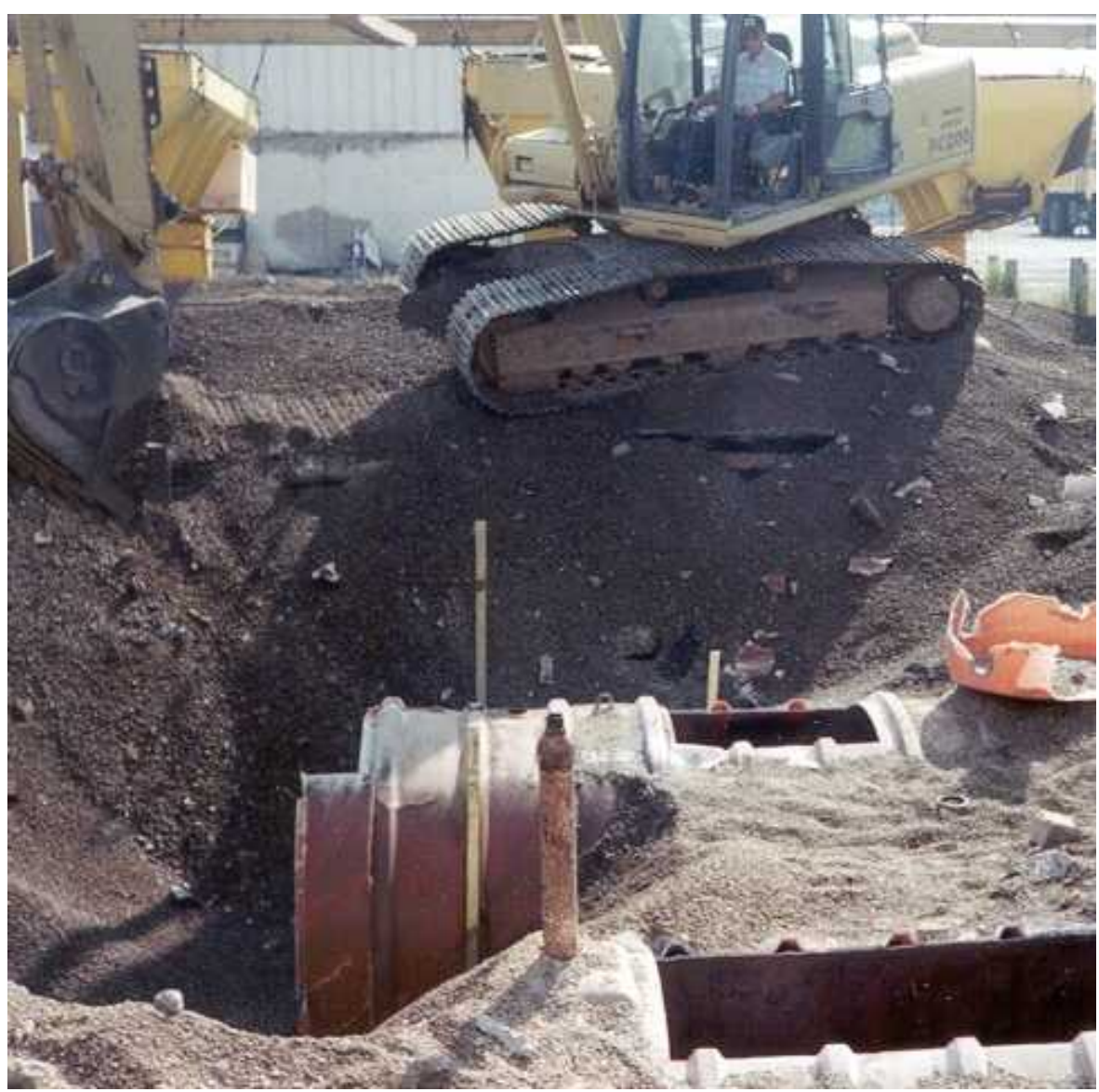

Figure 6. Excavator removing an underground storage tank

(source: http://www.in.gov/dot/programs/environment/images/TankYank.jpg)

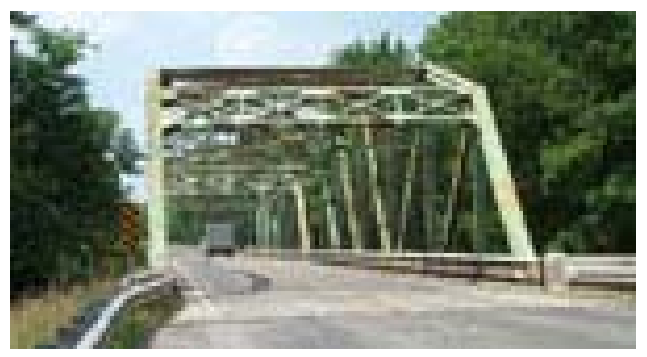

Figure 7. Many INDOT bridges have been painted with lead-based paint. (Source: http://www.in.gov/dot/div/envassess/bridges/br7c2.html)

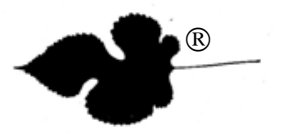

PhytoRemediate $^{\circledR}$ : Phytoremediation Decision Guide for Transportation Engineers 
Hazardous materials spills: Hazardous materials spills are not very common for INDOT sites. These spills occur sporadically and the information about the spill is reported directly to Indiana Department of Environmental Management (IDEM). Subsequently, INDOT identifies the responsible parties and determines the required cleanup in coordination with IDEM. However, INDOT is faced with a dilemma when they are not able to identify or locate the responsible parties. In this case, INDOT incurs the cost of cleanup. The exact number of these incidents is unknown.

Deicing salts: Surface water run-off from highways and storage of deicing salts result in potential environmental problems for INDOT. Highway run-off water laden with deicing salts has a maximum impact on soils and receiving water bodies during spring. This impact is negligible in summer and in fall is non-existent. However, the main environmental concern from INDOT's point of view is the run-off resulting from the uncovered salt storage at a few sites in the state.

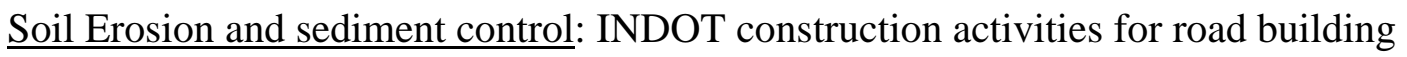
results in soil erosion. Soil erosion and sediment control measures are undertaken by INDOT by hiring contractors who reclaim impacted soils. One option is the use of vegetation to stabilize impacted soils. INDOT receives at least five or six noncompliance notices for soil erosion and sediment control problems per year. Identifying the sites requiring soil erosion and sediment control, and implementing plant stabilization is seen as the least expensive option.

Apart from the above mentioned problems, INDOT also faces other environmental issues such as the mitigation of impacted natural wetlands and the existence of roadside landfills. Natural wetlands are impacted because of construction activities of INDOT. Regulations require INDOT to mitigate any impacts on wetlands through restoration of the impacted area. INDOT also has encountered problems resulting from the roadside landfills that are present on the properties acquired for their

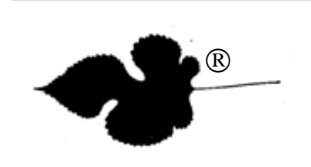

PhytoRemediate $^{\circledR}$ : Phytoremediation Decision Guide for (C)2004 Purdue University Transportation Engineers 
facilities. Problems like landfill leachate are reported to be of concern, however, no information about the nature or the pollution load of leachate is available.

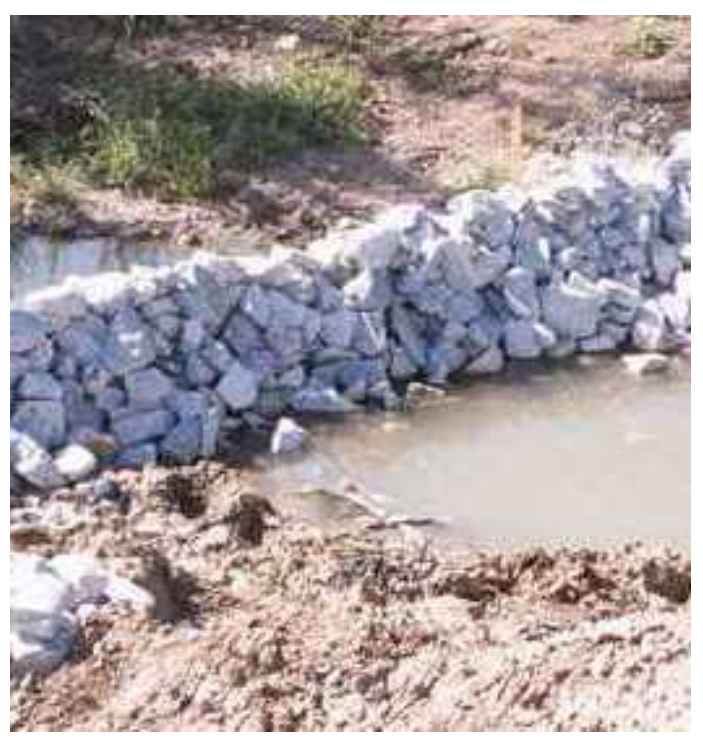

Figure 8. Soil erosion control implemented by INDOT

(source: http://www.in.gov/dot/programs/environment/images/checkdampane.jpg)

\subsection{Phytoremediation Case Studies}

The success of using phytoremediation is typically site-specific and, as a result, examination of various case studies can be very helpful to professionals. The case studies included briefly describes the basic on-site conditions. These conditions may include contaminant concentrations and the extent of the contamination; project implementation details such as the objectives and the basic engineering design; results to date; and contact information or references for written material relative to the specific project.

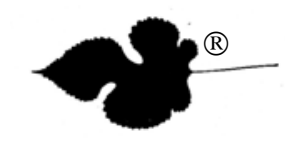

PhytoRemediate ${ }^{\circledR}$ : Phytoremediation Decision Guide for @2004 Purdue University Transportation Engineers 


\subsection{Phytoremediation Case Study \#1: J-Field, Aberdeen Proving Ground, Edgewood, Maryland}

\subsubsection{Problem Statement}

The J-Field, Aberdeen Proving Ground project, a five-year phytoremediation project, is a contaminated site of one acre. This field demonstration is one of the most extensively studied phytoremediation projects in the United States. The contaminants are 1,1,2,2-tetrachloroethane (1,1,2,2-TeCA) and trichloroethene (TCE) in the soil and groundwater.

\subsubsection{Phytoremediation Application}

One hundred and eighty three hybrid poplar trees ( $P$. deltoides $x$ trichocarpa) were planted in 1997. The objective was to contain a volatile organic compound (VOC) plume and reduce contaminant mass through transformation and transpiration using phytoremediation and hydrologic control. An additional 150 hybrid poplars as well as 450 native trees (species such as tulip trees, silver maples, evergreen hollies, loblolly pines, oaks, and willows) were also planted. Conventional remediation technologies have been tested on-site, but the presence of unexploded ordnance, a low permeability aquifer, and the continuously-fed contaminant plume hindered the progress of phytoremediation. The low groundwater velocity on-site and presence of an adjacent freshwater marsh are factors that enhanced the effectiveness of phytoremediation for this particular project.

The MODFLOW and earthVision models were used to estimate site-specific inputs on hydrology, transpiration and biodegradation, and aquifer and plume characterization.

The models demonstrated that the poplar trees have the potential to remove up to $360 \mathrm{lbs}$ per year of VOCs in 30 years. In addition, dense non-aqueous phase liquid (DNAPL) was recently discovered on-site.

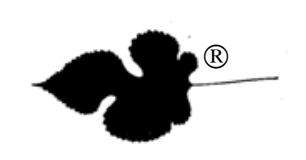

C2004 Purdue University

PhytoRemediate $^{\circledR}$ : Phytoremediation Decision Guide for Transportation Engineers 


\subsubsection{Results}

The increase in transpiration rates of the planted hybrid poplar trees and adjacent native forest has caused a hydraulic cone of depression in the center of the plantation. This depression has caused a reversal of groundwater flow into the plantation in the summertime, rather than towards the adjacent marsh. Transpiration rates were estimated using sap flow analysis and local weather data. Results indicate that it will take about 10 to15 years to achieve maximum transpiration rates of 2000 gallons per day. The leaf area index method was also used as a means of predicting the time of canopy closure, which coincides with the peak transpiration rate. Approximately three to six more years are needed to attain almost complete canopy closure. The volatilization research revealed that leaves do not transpire the bulk of the contaminants and therefore the degree of volatilization of harmful gases from the trees was found to be minimal. Results are showing evidence of biotic and abiotic degradation and lowered concentrations of VOCs in the groundwater. It is believed that the poplars are also enhancing in situ biodegradation of the contaminants. The contaminant reduction due to phytoremediation is primarily due to phytodegradation, phytovolatilization, and rhizodegradation.

Contact: Steven Hirsh, U. S. Environmental Protection Agency.

\subsection{Phytoremediation Case Study \#2: Kauffman \& Minteer, Jobstown, New Jersey}

\subsubsection{Problem Statement}

This is a five acre Superfund site consisting of a garage/office building, a former truck washing area, a former collection pit area, a drainage ditch, and a former unlined lagoon. Discharge from the lagoon and washing area has contaminated the shallow groundwater

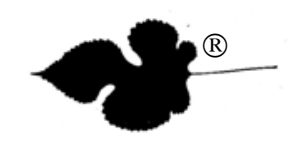

PhytoRemediate $^{\circledR}$ : Phytoremediation Decision Guide for (C)2004 Purdue University Transportation Engineers 
on site, and threatened the Wenonah-Mount Laurel aquifer, a source of drinking water for the community.

\subsubsection{Phytoremediation Application}

Phytoremediation started in 1998 when 75 hybrid poplar (P. maximowiczii $x$ trichocarpa) and native black willow (Salix nigra) were planted in the former lagoon and drainage ditch areas. The objectives of this phytoremediation study were: 1) to examine the capacity of the trees to mitigate shallow soil and groundwater contamination at the planting sites, and 2) to prevent migration of the contaminant plume by hydrologic control. A contaminant ion was primarily cis-1,2-DCE and TCE.

\subsubsection{Results}

It is too early to assess the success of phytoremediation at this site. In 2001, some of the wells actually had an increase in TCE, cis-1,2- DCE, and vinyl chloride concentrations since initial data were collected 1998 and September 1999. This may be due to soil excavation and backfilling at the drainage ditch and former truck wash area. Recent transpiration gas samples showed insignificant amounts of TCE, and significant amount of water uptake by the trees (hydrologic control).

Contact: George Prince, U. S. Environmental Protection Agency.

\subsection{Phytoremediation Case Study \#3: Vernal Naples Truck Stop, Vernal, Utah}

\subsubsection{Problem Statement}

The Vernal Naples Truck Stop site is an example of using phytoremediation as a polishing step to clean up remaining contaminants after a faster, more conventional

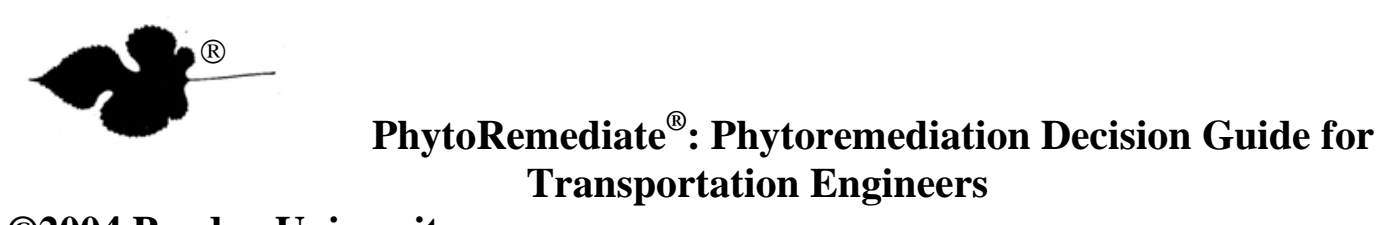

(C)2004 Purdue University

\section{Transportation Engineers}


technology has sufficiently reduced contaminant levels by vacuum-enhanced pumping/biotreatment, thermal oxidation, and granular activated carbon filtration.

\subsubsection{Phytoremediation Application}

In 1998, phytoremediation began with the planting of approximately 300 poplar trees cross-gradient of the gasoline and MTBE plume.

\subsubsection{Results}

In 2000, 25 percent of the trees died and 35 percent were highly stressed due to insecticide spraying or a lack of irrigation. These trees were replaced with 50 more poplar trees in 2001. Gasoline concentrations have decreased since 1998.

In 2000, the MTBE plume moved down-gradient and off-site at a faster rate than the gasoline plume. Groundwater elevation contours do not indicate hydrologic effects from the planted trees.

Contact: Hays Griswold, U. S. Environmental Protection Agency.

\subsection{Phytoremediation Case Study \#4: Tibbetts Road, Barrington, New Hampshire}

\subsubsection{Problem Statement}

The Tibbetts Road Superfund site is a two-acre site that was once used for the storage of drums containing thinners, solvents, antifreeze, kerosene, motor oil, polychlorinated biphenyls (PCBs), grease, and brake fluid. EPA has been working on the site since 1984, removing drums, excavating contaminated soil, and pumping and treating the contaminated groundwater.

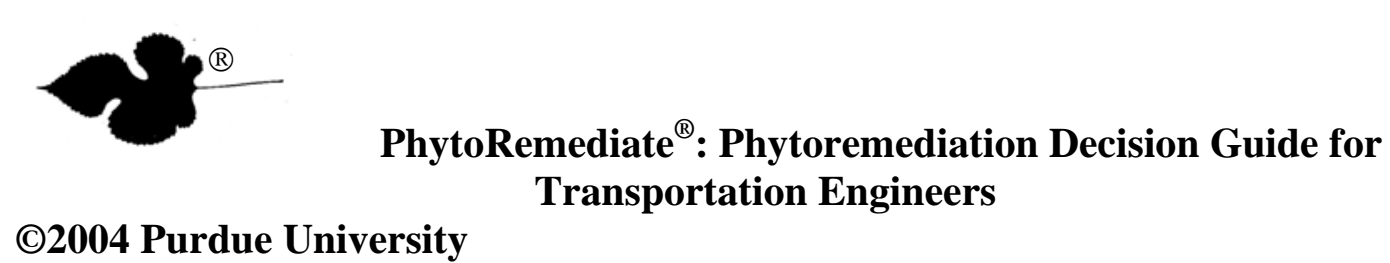




\subsubsection{Phytoremediation Application}

Approximately 1,400 hybrid poplars (one-year-old rooted $P$. deltoides $x$ nigra) were planted in 1998 as a final polishing step after several years of active treatment at the site using vacuum extraction. Phytoremediation was chosen for the site primarily as a means of providing hydrologic control of the contaminant plume.

\subsubsection{Results}

In 2001, there was a decrease in the concentrations of VOCs in groundwater at the site. The water levels in the overburden aquifer decreased and no cone of depression has been observed. The effectiveness of phytoremediation on the groundwater hydrology is uncertain at this time.

Contact: Neil Handler, U. S. Environmental Protection Agency.

\subsection{Phytoremediation Case Study \#5: Former Chevron Light Petroleum Products Terminal, Ogden, Utah}

\subsubsection{Problem Statement}

From the 1950s until 1989, Chevron stored and transferred petroleum products on this five-acre facility. The groundwater is contaminated with BTEX and other petroleum hydrocarbons.

\subsubsection{Phytoremediation Application}

In 1996, 40 poplar trees ( $P$. deltoides $x$ nigra) were planted in rows and were installed perpendicular to the direction of groundwater flow.

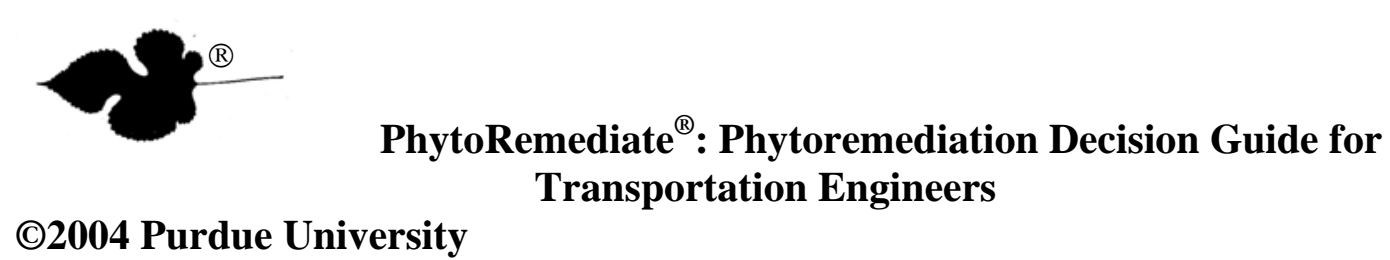




\subsubsection{Results}

No zone of depression was observed under the trees. However, in 2000, a decrease in both BTEX and petroleum hydrocarbon concentrations had been observed.

Contact: Nickolee Zollinger, Phytokinetics, Inc.

\subsection{Phytoremediation Case Study \#6: Magic Marker Site}

\subsubsection{Problem Statement}

Phytotech, Inc. (purchased by Edenspace Systems Corporation of Reston, Virginia in June, 1999) used soil amendments (i.e., ethylenediaminetetraacetic acid or EDTA) and hyperaccumulating plants to extract and accumulate lead and other metals from shallow soils. This phytoremediation was initiated in May 1997 at the former Magic Marker factory in Trenton, New Jersey. This urban brownfield is a 3 hectare (7 acre) site that used to be a lead-acid battery manufacturing company (Blaylock et al., 1997 and McCutcheon and Schnoor, 2003).

\subsubsection{Phytoremediation Application}

The primary objectives of this project were to establish the effectiveness of the plants used as hyperaccumulators and to determine if these plants would reduce soil lead in surface soils (6 inches) on-site. Indian mustard (Brassica juncea) and sunflower (Helianthus annus) were the plants selected to extract lead from the contaminated soils.

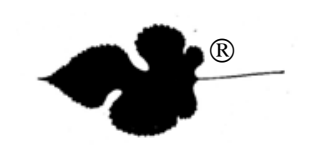

PhytoRemediate $^{\circledR}$ : Phytoremediation Decision Guide for Transportation Engineers

C2004 Purdue University 


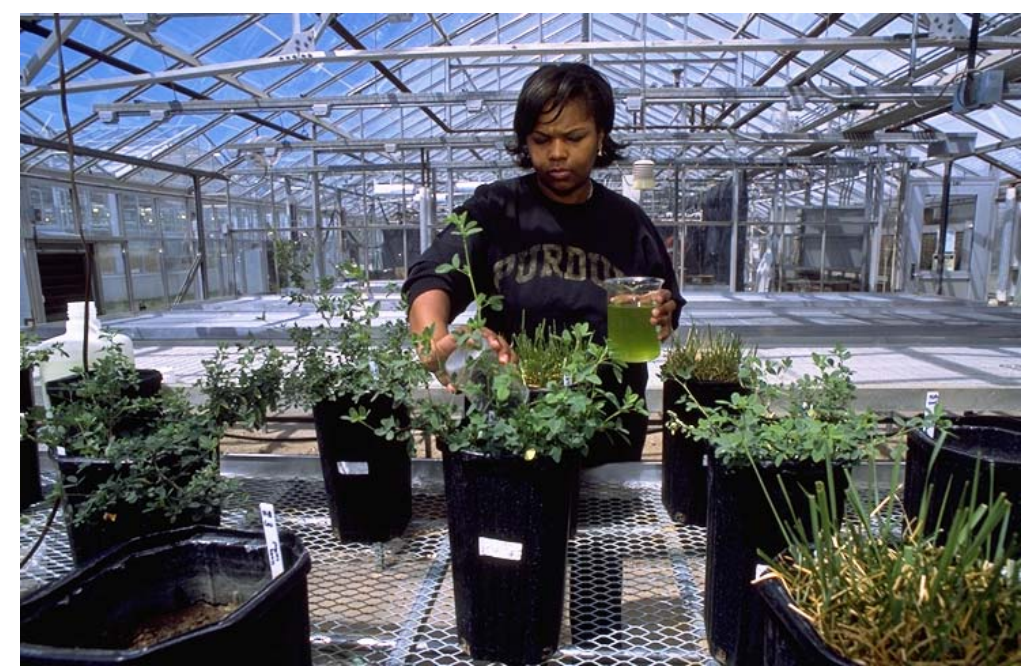

Figure 9. Phytoremediation greenhouse study.

\subsubsection{Results}

The Indian mustard and sunflower were able to accumulate lead in the aboveground plant tissue. All plants were able to exceed the project objective of a minimum lead uptake of 200 milligrams per kilogram of contaminated soil. There were differences between the amount of lead measured in plant shoots and the lead reduction measured in the soil from the treatment plot. The plant uptake alone did not account for the reductions encountered in the soil having the level of reduction was consistent with the mass of lead removed using plant uptake data.

\subsection{Phytoremediation Case Study \#7: Constructed Wetlands for the Remediation of Slag Leachates}

\subsubsection{Problem Statement}

Blast-furnace slag, a by-product of steel production, is recycled and often used as fill material for roads and other transportation structures. In and around I-65 and I-80/94 in Northwestern Indiana, this material is generating unsightly leachate with an extremely

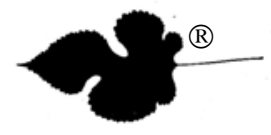

\section{PhytoRemediate $^{\circledR}$ : Phytoremediation Decision Guide for} (C)2004 Purdue University Transportation Engineers 
unpleasant smell. The resulting reaction stems from under-weathered slag mixing with runoff to produce a greenish leachate, exhibiting high $\mathrm{pH}$ and hydrogen sulfide odor. This leachate has become a nuisance because of occurrence in public parks, and has forced the Indiana Department of Transportation to take remedial action.

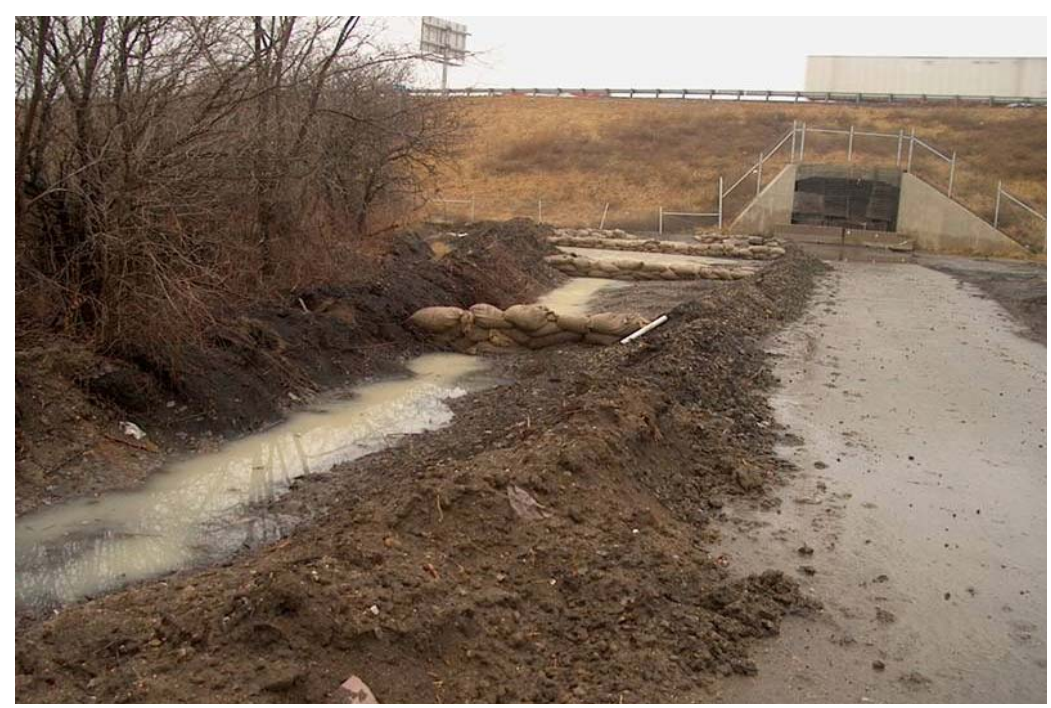

Figure 10. Interstate 65 site in May 2002.

\subsubsection{Phytoremediation Application}

The overall objective of this project is to explore the use of constructed wetlands as a means to biologically and chemically eliminate the negative properties of the leachate. Field scale constructed wetlands have been constructed to treat the slag leachate at two locations. The design involves subsurface wetland cell placement to create anoxic conditions that would reduce total sulfur, high $\mathrm{pH}$, and other pollutants, along with limiting open water exposure and nuisances.

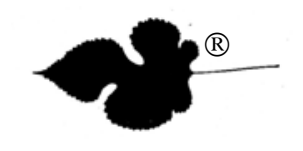

PhytoRemediate $^{\circledR}$ : Phytoremediation Decision Guide for (C)2004 Purdue University Transportation Engineers 


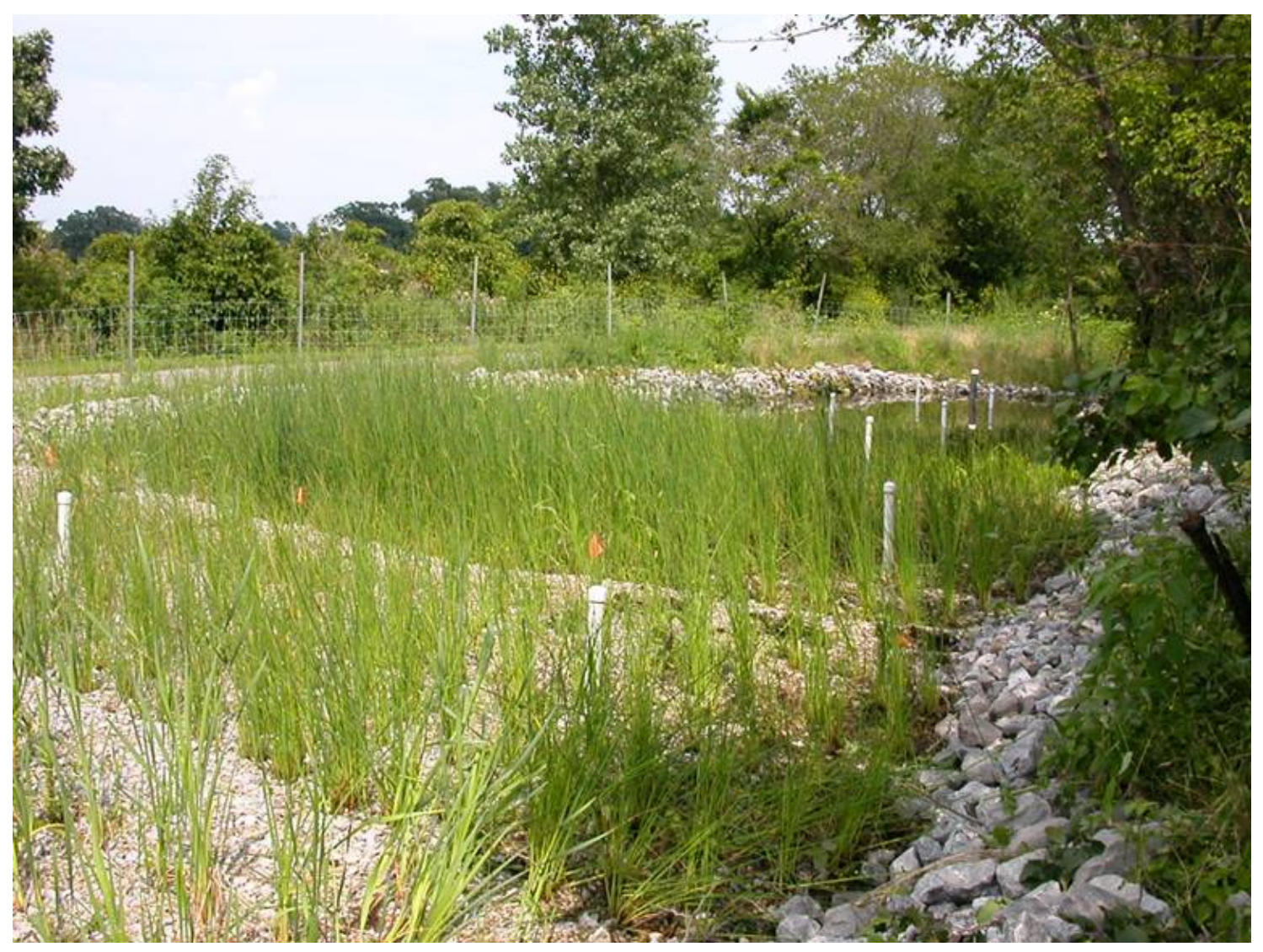

Figure 11. Interstate 65 site in late July 2003 showing the constructed wetlands.

\subsubsection{Results}

Laboratory and greenhouse studies are also testing the leachability of the slag material, constituents of the slag leachate, as well as possible media and plant combinations to use within the constructed wetland system.

Contact: James Hunter, Jason Hickey, M. Katherine Banks, and A. Paul Schwab, Purdue University.

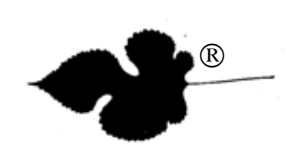

PhytoRemediate $^{\circledR}$ : Phytoremediation Decision Guide for C2004 Purdue University Transportation Engineers 


\subsection{Flowchart/Decision-Tree}

Emphasis was placed on the following components and/or questions in the development of the decision tree/flowchart used in PhytoRemediate ${ }^{\circledR}$ : Phytoremediation Decision Guide for Transportation Engineers:

1. What type of contamination is present (specifically integrate the environmental problems identified by INDOT)?

2. Is phytoremediation a preliminary consideration?

3. Will Indiana climate support the proposed plants (plants suited to site conditions?)

4. Is time of remediation or space requirements a constraint?

5. Is the contaminant physically within the range of the plant roots (rhizosphere)?

6. Will plants be used for hydrologic control ONLY (i.e., to prevent movement of the contaminants)?

7. Will water be applied to the phytoremediation system for irrigation?

8. Will Indiana regulations allow this type of phytoremediation treatment?

9. Is the contaminant phytotoxic?

10. Will the rhizosphere microbes and plant-exudates degrade the target contaminants in the rhizosphere?

11. Is the $\log \mathrm{K}_{\mathrm{ow}}$ of the contaminant or metabolic products between 1 and 3.5 (hydrophobicity)?

12. Will the plants degrade the contaminant after uptake?

13. Will the plants accumulate the contaminant?

14. Is the level of accumulation acceptable for this site?

15. Can controls be used to prevent the transfer of the contaminant or metabolic products to the ecosystem?

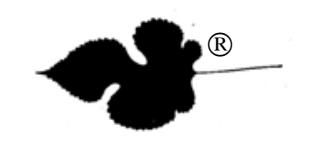

PhytoRemediate $^{\circledR}$ : Phytoremediation Decision Guide for (C)2004 Purdue University Transportation Engineers 
16. Is the quantity and rate of transpiration acceptable for this site?

17. Does the plant material (if harvested) constitute a waste?

18. Can the contaminant or metabolites be immobilized to acceptable levels?

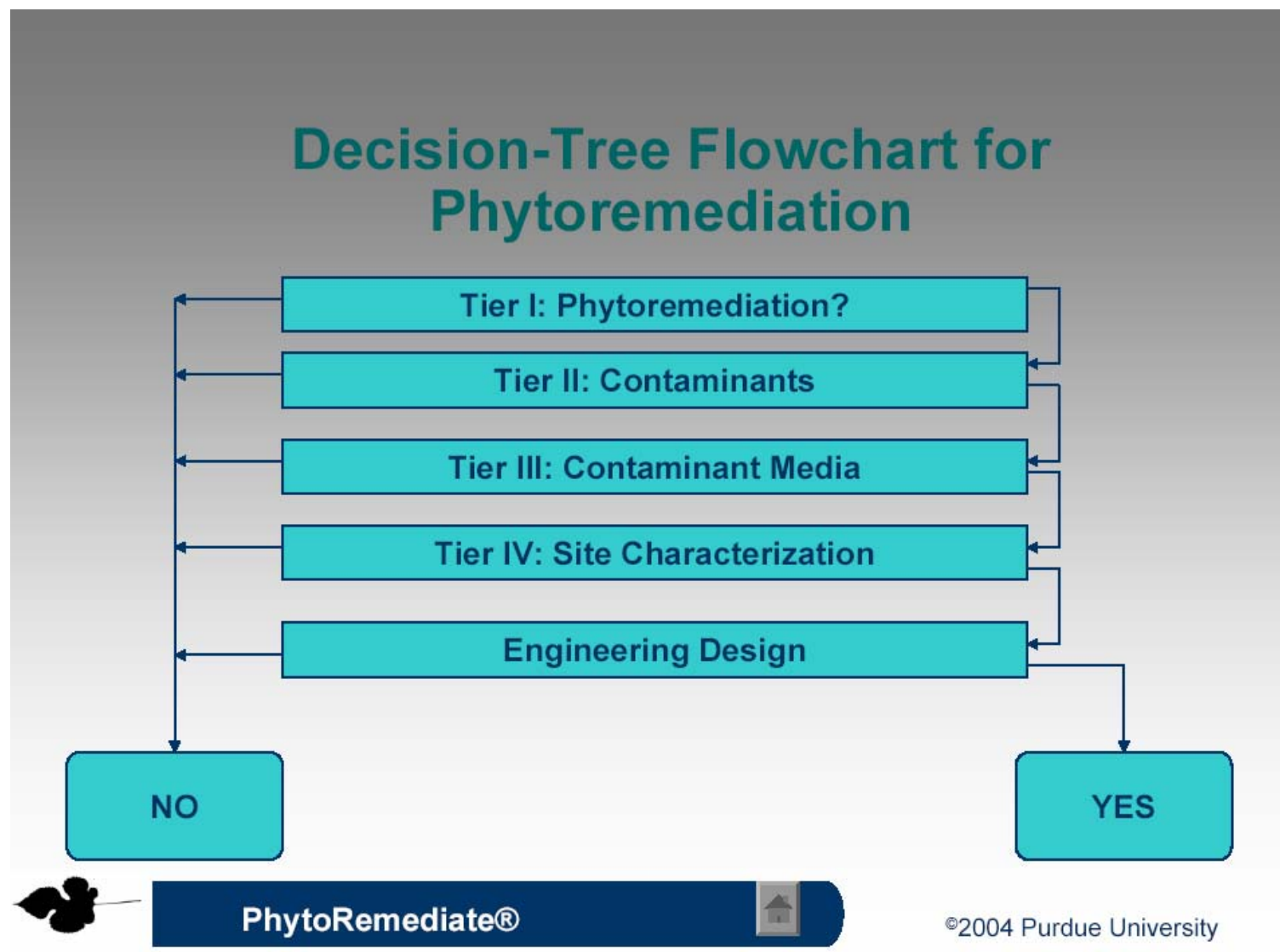

Figure 12. Decision-Tree Flowchart for Phytoremediation

\subsubsection{Tier I: Phytoremediation?}

The main consideration in Tier I of the decision-tree flowchart is whether or not phytoremediation is a preliminary consideration for the cleanup of a particular site. If phytoremediation is a preliminary consideration, one must proceed in the decision-tree flowchart to Tier II for the characterization of the contaminants. It is important to note that not all contaminated sites are suitable for phytoremediation.

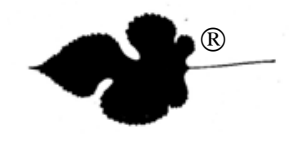

\section{PhytoRemediate $^{\circledR}$ : Phytoremediation Decision Guide for} (C)2004 Purdue University Transportation Engineers 


\subsubsection{Tier II: Contaminants}

Tier II of the decision-tree flowchart considers a complete characterization of all known contaminants to be considered for site remediation. One should refer especially to section 4d. on the PhytoRemediate ${ }^{\circledR}$ : Preliminary Phytoremediation Design Checklist when dealing with the known and characterized contaminants that are present on the site and then proceed to Tier III (Contaminant Media).

\subsubsection{Tier III: Contaminant Media}

The main consideration in Tier III of the decision-tree flowchart is to determine the contaminant media that are affected on the site. One should refer especially to the “Contaminant Media” sections on the PhytoRemediate ${ }^{\circledR}$ : Preliminary Phytoremediation Design Checklist when dealing with the known and characterized contaminants that are present on the site. The contaminant media may be air, surface water, groundwater, soil, sediment, sludge (biosolids), or even a combination of these media. This will very likely involve subsurface exploration to determine the nature and the extent of the contamination and then proceed to Tier IV (Site Characterization).

\subsubsection{Contaminated Media Considerations}

Phytoremediation can be used for in situ or ex situ applications. Phytoremediation is generally considered for in situ use by establishing vegetation in areas of contaminated soil or groundwater. However, soil can be excavated and placed into a treatment unit where phytoremediation can be applied. Groundwater or surface water can be pumped into a treatment unit established for phytoremediation or it can be sprayed onto vegetation.

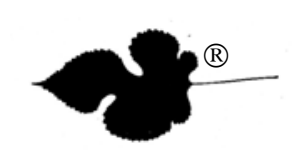

PhytoRemediate $^{\circledR}$ : Phytoremediation Decision Guide for (C)2004 Purdue University Transportation Engineers 


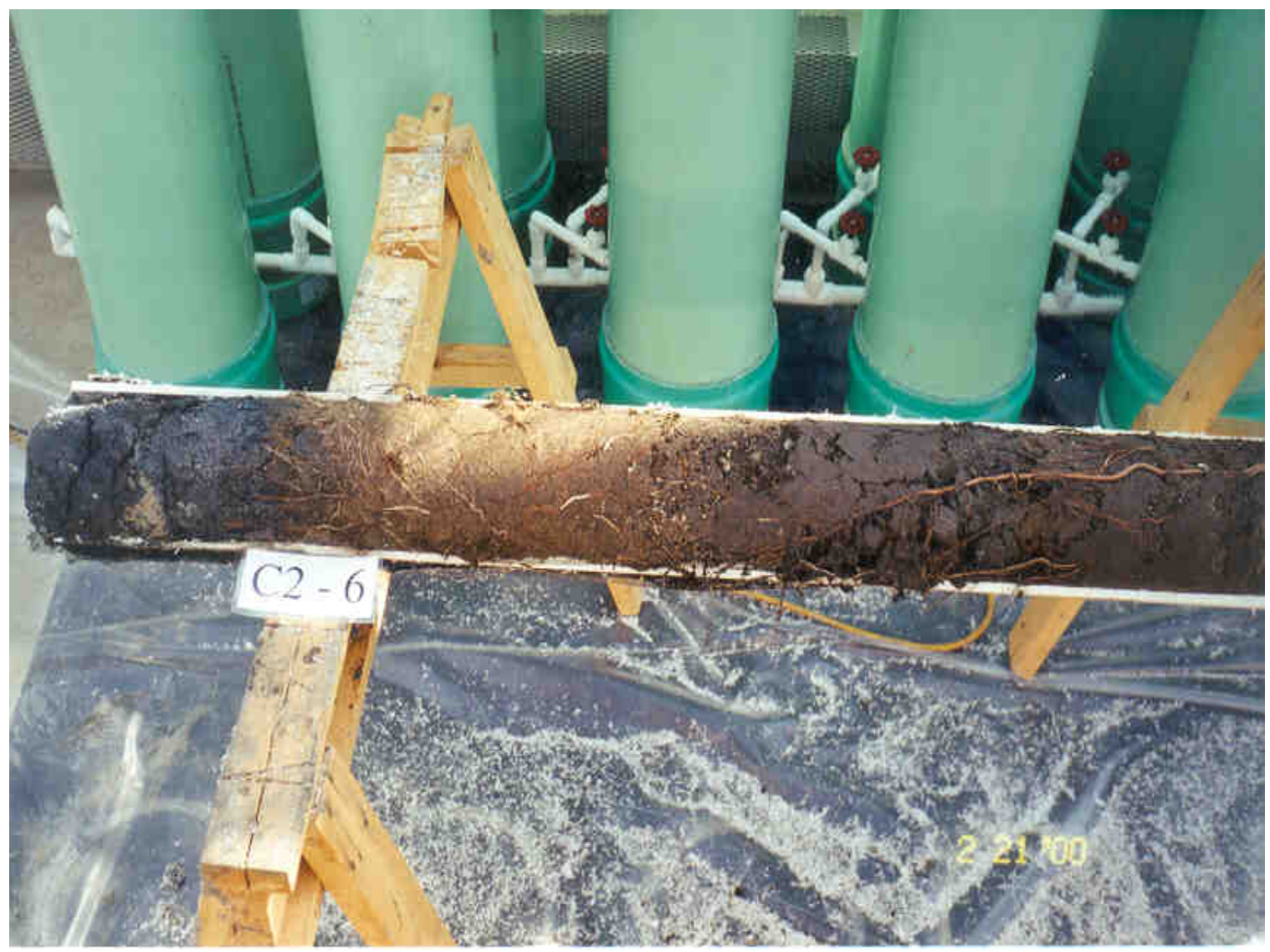

Figure 13. Contaminated soil core.

\subsubsection{Phytoremediation of contaminant media: Soil, sediment, and sludge}

The primary considerations for phytoremediation of soil are the depth and volume of contamination and soil characteristics that affect plant growth, such as texture and water content (degree of saturation). Phytoremediation is most appropriate for large areas of low to moderately contaminated soil that would be prohibitively expensive to remediate using conventional technologies. The contaminated soil should be within the root zone depth (rhizosphere) of the selected plant. Small volumes of contaminated soil concentrated in just a few areas are likely to be more efficiently remediated using other technologies.

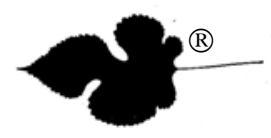

PhytoRemediate $^{\circledR}$ : Phytoremediation Decision Guide for (C)2004 Purdue University Transportation Engineers 


\subsubsection{Phytoremediation of contaminant media: Groundwater}

When groundwater contamination is encountered, phytoremediation can be used as a means of cleaning up a contaminant plume. The following phytoremediation technologies are used in the treatment of groundwater: phytodegradation, phytovolatilization, rhizofiltration, hydrologic control (plume control), vegetative cover, riparian corridors/buffer strips.

\subsubsection{Phytoremediation of contaminant media: Surface water}

When surface water contamination is encountered, one of the proven phytoremediation technologies used is constructed treatment wetlands. An example of this technology is found in the INDOT project described briefly in Case Study \#7 found in Section 3.7.

\subsubsection{Tier IV: Site Characterization}

The main consideration in Tier IV is to properly and adequately characterize the contaminated site. The last section of the PhytoRemediate ${ }^{\circledR}$ : Preliminary Phytoremediation Design Checklist involves the site characterization. One must consider several environmental factors in order to properly and adequately characterize a contaminated site, such as climate, the length of the growing season, soils, hydrogeology, and topography to name a few. An excellent resource on site characterization is "Chemical and Physical Characterization of Soils" (Schwab, 1992). The site characterization phase may necessitate further sampling of the contaminated media. The preliminary consideration of applicable plants to use in the phytoremediation design will occur after site characterization is completed. In Tier IV, all of the information relative to contamination, contaminant media, and site characterization are integrated into the phytoremediation engineering design.

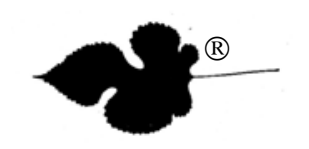

PhytoRemediate $^{\circledR}$ : Phytoremediation Decision Guide for (C)2004 Purdue University Transportation Engineers 


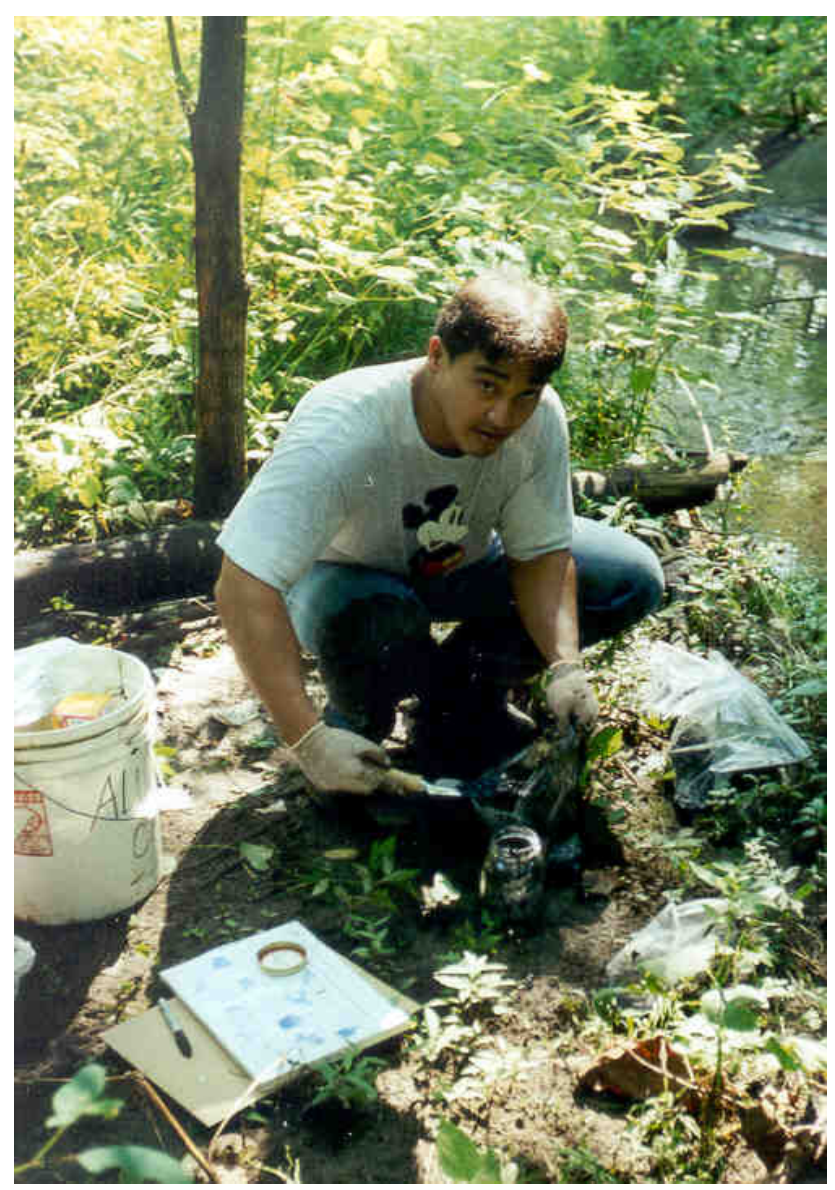

Figure 14. Site characterization of contaminated soil.

\subsubsection{Engineering Design}

The following is a preliminary phytoremediation design checklist to be used by transportation engineers and other professionals to determine the applicability of phytoremediation as an effective method of remediation. It is imperative that INDOT establish the following: (1) whether phytoremediation is a preliminary option or consideration, (2) a characterization of the contaminants on the site, and (3) characterization and determination of the contaminant media, (4) site characterization, and (5) identification of the integral components of phytoremediation engineering design.

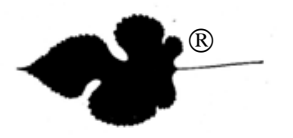

\section{PhytoRemediate $^{\circledR}$ : Phytoremediation Decision Guide for Transportation Engineers}




\subsubsection{Phytoremediation System Selection and Engineering Design Considerations}

A decision-making process for evaluating whether or not phytoremediation is a viable option is provided by the following outline of the steps for applying phytoremediation:

- Define Problem

- Conduct site characterization

- Identify the problem: media/contaminant

- Identify regulatory requirements

- Identify remedial objectives

- Establish criteria for defining the success of the phytoremediation system

- Evaluate site for use of phytoremediation

- Perform phytoremediation-oriented site characterization

- Identify phytoremediation technology that addresses contaminant media/contaminant/goals

- Review known information about identified phytoremediation technology

- Identify potential plant(s)

- Conduct preliminary studies and make decisions

- Conduct screening studies

- Perform optimization studies

- Conduct field plot trials

- Revise selection of phytoremediation technology, if necessary

- Revise selection of plant(s), if necessary

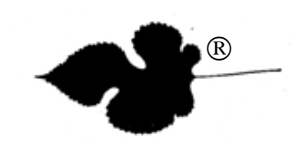

PhytoRemediate $^{\circledR}$ : Phytoremediation Decision Guide for (C)2004 Purdue University Transportation Engineers 
- Evaluate full-scale phytoremediation system

- Design system

- Construct system

- Maintain and operate system

- Evaluate and modify system

- Evaluate performance

- Achieve objectives

- Perform quantitative measurement

- Meet criteria for success 


\subsection{PhytoRemediate ${ }^{\circledR}$ : Preliminary Phytoremediation Design Checklist}

Following the process of going through the decision-tree flowchart for phytoremediation: Tier I (Phytoremediation), Tier II (Contaminants), Tier III (Contaminant Media), Tier IV (Site Characterization), and the engineering designs, one should carefully evaluate this preliminary phytoremediation design checklist as an integral component of the engineering design.

Site Name:

$\square$ Is phytoremediation a consideration? (Tier I):

Description of contamination (Tier II):

Applicable Regulations:

$\square$ Contaminant Media (Tier III):

1) Air Contamination: Yes $\square$ No $\square$

2) Surface Water Contamination: Yes $\square$ No $\square$

3) Subsurface Water Contamination: Yes $\square$ No $\square$

a) Depth of groundwater:

i) $\square<3$ feet

ii) $\square$ 3-8 feet

iii) $\square>8$ feet

4) Soil Contamination: Yes $\square$ No $\square$

a) $\square$ soil $\mathrm{pH}$ :

i) $\square>8$

ii) $\square$ 6-8

iii) $\square<6$

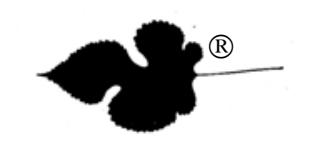

PhytoRemediate $^{\circledR}$ : Phytoremediation Decision Guide for Transportation Engineers

(C)2004 Purdue University 
b) $\square$ Soil textural class (USDA):

i) $\square$ fine?

ii) $\square$ medium?

iii) $\square$ coarse?

c) $\square$ Soil order from Soil Taxonomy (USDA):

1.

2. $\square$ Contaminants

i. $\square$ Arsenic $>40 \mathrm{mg} \mathrm{kg}^{-1}$

ii. $\square$ Boron $>3 \mathrm{mg} \mathrm{kg}^{-1}$

iii. $\square$ Cadmium $>15 \mathrm{mg} \mathrm{kg}^{-1}$

iv. $\square$ Chromium (total) $>1000 \mathrm{mg} \mathrm{kg}^{-1}$

v. $\square$ Copper $>200 \mathrm{mg} \mathrm{kg}^{-1}$

vi. $\square$ Mercury $>20 \mathrm{mg} \mathrm{kg}^{-1}$

vii. $\square$ Nickel $>100 \mathrm{mg} \mathrm{kg}^{-1}$

viii. $\square$ Zinc $>500 \mathrm{mg} \mathrm{kg}^{-1}$

ix. $\square$ Cyanides (total) $>250 \mathrm{mg} \mathrm{kg}^{-1}$

x. $\square$ Phenols $>20 \mathrm{mg} \mathrm{kg}^{-1}$

xi. $\square$ Sulfates $>2000 \mathrm{mg} \mathrm{kg}^{-1}$

xii. $\square$ Tars (as PAHs) $>1000 \mathrm{mg} \mathrm{kg}^{-1}$

xiii. $\square$ Petroleum products $>100 \mathrm{mg} \mathrm{kg}^{-1}$

d) $\square$ Depth of soil contamination:

i) $\square<6$ inches

ii) $\square$ 6-12 inches

iii) $\square$ 12-20 inches

iv) $\square>20$ inches

5) $\square$ Sediment Contamination : Yes $\square$ No $\square$

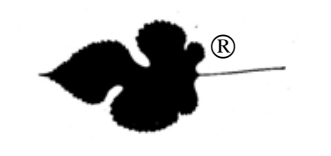

PhytoRemediate $^{\circledR}$ : Phytoremediation Decision Guide for (C2004 Purdue University Transportation Engineers 
6) $\square$ Sludge/Biosolids Contamination : Yes $\square$ No $\square$

Site Characterization (Tier IV):

1. On-site/site-specific data available? : Yes $\square$ No $\square$

2. Laboratory data available? : Yes $\square$ No $\square$

3. Climate suitable for plants? : Yes $\square$ No $\square$

4. Length of growing season? : Yes $\square$ No $\square$ Specify:

5. USDA plant hardiness zone? : Yes $\square$ No $\square$ Specify:

6. Minimum temperature at site:

7. $\square$ Average annual precipitation at site:

8. $\square$ Drought probability:
a. $\square$ Low?
b. $\square$ Medium?
c. $\square$ High?

9. $\square$ Plants to be considered for phytoremediation:

10. $\square$ Hydrologic control necessary? : Yes $\square$ No $\square$

11. $\square$ Type of phytoremediation to be used:
a. $\square$ Phytotransformation
b. $\square$ Phytoextraction
c. $\square$ Phytostabilization
d. $\square$ Rhizofiltration/Rhizosphere bioremediation
e. $\square$ Phytovolatilization
f. $\square$ Hydrologic control
g. $\square$ Riparian corridors and buffer strips
h. $\square$ Vegetative cover

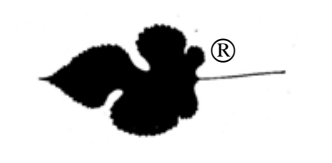

PhytoRemediate $^{\circledR}$ : Phytoremediation Decision Guide for @2004 Purdue University Transportation Engineers 


\subsection{Plant selection process for phytoremediation}

The plant selection process (USEPA, 2000) is an essential component of the phytoremediation engineering design. It is imperative to identify the specific phytoremediation technology and remedial goals to clean-up a contaminated site.

A site evaluation consists of the following:

- Location (also relative to plant/vegetation/ecosystem zones)

- Temperatures: averages, range

- USDA plant hardiness zone (range of average annual minimum temperature)

- Precipitation: amount, timing

- Length of growing season

- Amount of sun/shade

- Soil texture, salinity, pH, fertility, water content, structure (hardpans, etc.)

- Contaminant type, concentration, form

- Site-specific conditions or considerations

- Identify plants growing in contaminated portion of site.

- Do these provide information as to what plants to select?

- Will these plants compete with the selected plant?

- If the native plants do compete with the selected plant, are they easily removed?

- Identify local plants and crops.

- Do these plants provide information as to what plants to select?

- Will a selected plant interfere with local plants?

One must identify important criteria for plant selection to be used in the phytoremediation strategy. The following generalized criteria should be considered:

- Disease resistance

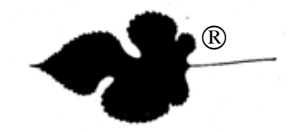

PhytoRemediate ${ }^{\circledR}$ : Phytoremediation Decision Guide for (C2004 Purdue University Transportation Engineers 
- Heat tolerance

- Cold tolerance

- Insect tolerance

- Drought resistance

- Salt tolerance

- Chemical tolerance

- Stress tolerance

- Legume/nonlegume

- Annual/biennial/perennial

- Cultural requirements: Due to the added stress of a contaminated soil environment, the cultivation and maintenance factors may have to be carefully monitored.

o Seed pretreatment before germination (such as for some prairie grasses)

o Planting method (seeds, sod, sprigs, whips, plugs, transplants), timing, density, depth (of seeds, root ball, or whips)

o Mulching, irrigation, soil $\mathrm{pH}$ control, fertilization, protection from pests and disease

o Fallen leaves, debris

o Harvesting requirements

o Labor and cost requirements should not be excessive

- Invasive, undesirable, or toxic characteristics

- Plant/seed source

- Establishment rate

o Reproduction method/rate

o Growth rate/biomass production

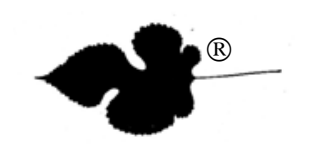




\subsection{Internet Resources on Phytoremediation}

- Technology Focus-Phytoremediation (USEPA): http://clu-in.org/publications/db/tp.cgi?technology=5

- USEPA Innovative Technologies(USEPA): http://www.epa.gov/tio/remed.htm

- Phytoremediation Online Decision Tree Document: http://www.itrcweb.org/user/webphyto/envdept/phyto/wwwphyto/

- Phytoremediation (Missouri Botanical Garden): http://www.mobot.org/jwcross/phytoremediation/

- Bioremediation and Phytoremediation Glossary: http://members.tripod.com/ bioremediation/

- International Journal of Phytoremediation: http://www.aehs.com/journals/phytoremediation/

- Ground-Water Remediation Technologies Analysis Center (GWRTAC) Phytoremediation Reports: http://www.gwrtac.org/html/topics/phytorem.htm

- The Phytoremediation of Organics Action Team, established in 1997, is one of the six active Action Teams under the Remediation Technologies Development Forum (RTDF): http://www.rtdf.org/public/phyto/default.htm

- Toolkit for Greener Practices: Decision Tree: http://www.pca.state.mn.us/programs/p2-s/toolkit/decisiontree.html

- Hazardous Substances Research Center, Kansas State University (HSRC) www.engg.ksu.edu/HSRC/phytorem/home.html

- Phytonet, University of Parma, Italy (PHYTONET) www.dsa.unipr.it/phytonet/

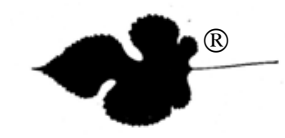




\subsection{Conclusions and Summary}

The use of the PhytoRemediate ${ }^{\circledR}:$ A Phytoremediation Decision Guide for Transportation Engineers will provide information for preliminary consideration during the decisionmaking process about the use of phytoremediation. Phytoremediation should be considered as a remediation option for the environmental problems listed below:

- Underground Storage Tanks (USTs) on properties acquired by INDOT for road construction and other developmental projects.

- Contamination of soils due to the use of lead-based paints on bridges.

- Hazardous materials and waste accidental spills.

- Impact of highway run-off water with deicing salts.

- Construction activities resulting in soil erosion. 


\subsection{References}

Alkorta, Itziar, and Carolos Garbisu. 2001. Phytoremediation of organic contaminants in soils. Bioresource Technol. 79:273-276.

Anderson, Todd A., Elizabeth A. Guthrie, and Barbara T. Walton. Bioremediation. Environ. Sci. Technol. 27(13):2630-2636.

Bader, D. F. 1996. Phytoremediation of explosives contaminated groundwater in constructed wetlands. IBC Conference, May 8-10, 1996, Arlington, VA.

Baker, A. J. M. 1995. Metal hyperaccumulation by plants: Our present knowledge of the ecophysiological phenomenon. In Interdisciplinary Plant Group (eds.), Will Plants Have a Role in Bioremediation?, Proceedings/Abstracts of the Fourteenth Annual Symposium, 1995, Current Topics in Plant Biochemistry, Physiology, and Molecular Biology, April 19-22, 1995, University of Missouri-Columbia.

Banks, M. K., A. P. Schwab, and R. S. Govindaraju. 1997. Assessment of phytoremediation field trials. $12^{\text {th }}$ Annual Conf. On Hazardous Waste Research, May 19-22, 1997, Kansas City, MO.

Bañuelos, G. S. 1996. Extended Abstract: Phytoremediation of Se applied to soils in municipal sewage sludge. First International Conference of Contaminants and the Soil Environment. February 21-28, 1996 Adelaide, South Australia.

Baker, A.J.M., S.P. McGrath, C.M.D. Sidoli, and R.D. Reeves. 1995. The potential for heavy metal contamination mining environmental management. September 12-14 [reprinted with permission from (1994). The possibility of in situ heavy metal decontamination of polluted soils using crops of metal-accumulating plants. Resources, Conservation and Recycling. 11, Elsevier Science B.V., Amsterdam, The Netherlands].

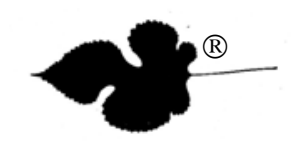


Blaylock, M. J., D. E. Salt, S. Dushenkov, O. Zakharova, C. Gussman, Y. Kapulnik, B. D. Ensley, and I. Raskin. 1997. Enhanced accumulation of Pb in Indian mustard by soil- applied chelating agents. Environ. Sci. Technol. 31:860-865.

Brooks, R.R., ed. 1998. Plants that hyperaccumulate heavy metals. CAB International, New York.

Brooks, R.R., J. Lee, R.D. Reeves, and T. Jaffre. 1977. Detection of nickeliferous rocks by analysis of herbarium specimens of indicator plants. J. Geochem. Explor. 7:4957.

Burckhard, S.R., K. Thompson, V.R. Schaefer, P. Kulakow, B. Leven, and A.P. Schwab. Vegetated treatment of vehicle wash sediments: Development of a decision support tree. Proceedings of the 2000 Conference on Hazardous Waste Research.

Carreira, L. H. 1996. Abstract: Enzymology of degradation pathways for TNI International Phytoremediation Conference. May 8-10, 1996. Arlington, VA.

Chaney, R.L. 1983. Plant uptake of inorganic waste constituents. In: Land treatment of hazardous wastes. J.E. Parr, P.B. March, and J.M. Kla, eds. Noyes Data Corp., Park Ridge, New Jersey, pp. 5-76.

Cornish, J. E., W. C. Goldberg, R. S. Levine, and J. R. Benemann. 1995.

Phytoremediation of soils contaminated with toxic elements and radionuclides. pp. 55-63. In R. E. Hinchee, J. L. Means, and D. R. Burris (eds.), Bioremediation of inorganics. Battelle Press, Columbus, $\mathrm{OH}$.

Crumbling, Deana M., Cheryl Groenjes, Barry Lesnik, Kira Lynch, Johnnette Schockley, Jeff Van Ee, Robert Howe, Larry Keith, and Jerry McKenna. 2001. Managing uncertainty in environmental decisions. Environ. Sci. Technol. October 1, 2001: 405A-409A

Cunningham, S.D. and W.R. Berti. 1993. Remediation of contaminated soil with green plants: An overview. In Vitro Cell. Dev. Biol. 29P:207-212.

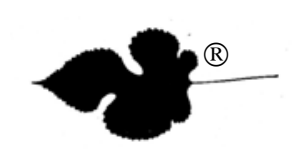
(C)2004 Purdue University Transportation Engineers 
Cunningham, S. D., and W. R. Berti, and J. W. Huang. 1995b. Phytoremediation of contaminated soils. Trends Biotechnol. 13:393-397.

Cunningham, S.D. and C.R. Lee. 1995. Phytoremediaiton: Plant-based remediation of contaminated soils and sediments. In: Bioremediation: Science and applications. Soil Science Society of America, Special Publication 43, Madison, Wisconsin, pp.145-156.

Cunningham, Scott D., Todd A. Anderson, A. Paul Schwab, and F.C. Hsu. 1996.

Phytoremediation of soils contaminated with organic pollutants. In: Advances in Agron. Academic Press, New York, 56:55-114.

Cunningham, Scott D., William R. Berti, and Jianwei W. Huang. 1995. Phytoremediation of contaminated soils. Trends in Biotechnology 13: 393-397.

Drake, E. N. 1997. Phytoremediation of Aged Petroleum Hydrocarbons in Soil. IBC Phytoremediation Conference, June 18-19, 1997, Seattle, WA.

Dushenkov, S., D. Vasudev, Y. Kapulnik, D. Gleba, D. Fleischer, K. C. Ting, and B. Ensley. 1997. Removal of uranium from water using terrestrial plants. Environ, Sci. Technol. 31(12):3468-3474.

Dushenkov, V., P.B.A.N. Kumar, H. Motto, and I. Raskin. 1995. Rhizofiltration: the use of plants to remove heavy metals form aqueous streams. Environ. Sci. Technol. 29(5): 1239-1245.

Fletcher, J. S., F. L. Johnson, and J. C. McFarlane. 1988. Database assessment of phytotoxicity data published on terrestrial vascular plants. Environ. Toxicol. Chem. 7:615-622.

Gatliff, E. G. 1994. Vegetative remediation process offers advantages over traditional pump-and-treat technologies. Remed. Summer. 4(3):343-352.

Glass, David. 2000. U.S. and international markets for phytoremediation, 1999-2000. D. Glass Associates, Inc., Needham, MA.

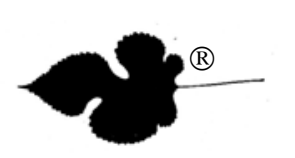

PhytoRemediate $^{\circledR}$ : Phytoremediation Decision Guide for (C)2004 Purdue University Transportation Engineers 
Henry, Jeanna R. 2000. An overview of the phytoremediation of lead and mercury. USEPA.

Interstate Technology \& Regulatory Council (ITRC). 1999. Phytoremediation decision tree. The Interstate Technology and Regulatory Cooperation Work Group, November 1999.

Interstate Technology \& Regulatory Council (ITRC). 2001. Phytotechnology technical and regulatory guidance document-draft. The Interstate Technology and Regulatory Cooperation Work Group, March 26, 2001.

Interstate Technology \& Regulatory Council (ITRC). 2002. Phytotechnologies workshop. November 19-21, 2002.

Kumar, P.B.A.N., V. Dushenkov, H. Motto, and I. Raskin. 1995. Phytoextraction: the use of plants to remove heavy metals from soils. Environ. Sci. Technol. 29(5): 12321238.

Lasat, Mitch M. 2000. The use of plants for the removal of toxic metals from contaminated soil. USEPA.

Licht, L. A. 1990. Poplar tree buffer strips grown in riparian zones for biomass production and nonpoint source pollution control. Ph.D. Thesis, University of Iowa, Iowa City,IA.

Macek, T., M. Macková, J. Káš. 2000. Exploitation of plants for the removal of organics in environmental remediation. Biotechnol. Adv. 18:23-34.

McCutcheon, S. C. 1995. Phytoremediation of hazardous waste. July 23-26.

McCutcheon, S. C., N.L. Wolfe, L.H. Carreira, and T.Y. Ou. 1995. Phytoremediation of hazardous waste. In: Innovative technologies for site remediation and hazardous waste management: Proceedings of the National Conference. R.D. Vidic and F.G. Pohland, eds Environemntal Engineering Division, American Society of Civil Engineers, New York, held in Pittsburg, Pennsylvania, July 26, pp.597-604.

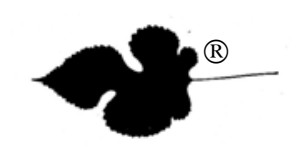

(C)2004 Purdue University

PhytoRemediate $^{\circledR}$ : Phytoremediation Decision Guide for Transportation Engineers 
McCutcheon, Steven C., and Jerald L. Schnoor. 2003. Phytoremediation: Transformation and control of contaminants. John Wiley \& Sons, Inc., Hoboken, New Jersey.

Mitsch, William J., and Sven Erik Jørgensen. 2004. Ecological engineering and ecosystem restoration. John Wiley \& Sons, Inc., Hoboken, New Jersey.

Nanda Kumar, P. B. A., V. Dushenkov, H. Motto, and I. Raskin. 1995. Phytoextraction: The use of plants to remove heavy metals from soils. Environ. Sci. Technol. 29(5):1232-1238.

Nellessen, J. E., and J. S. Fletcher. 1993a. Assessment of published literature on the uptake/accumulation, translocation, adhesion and biotransformation of organic chemicals by vascular plants. Environ. Toxicol. Chem. 12:2045-2052.

Nellessen, J. E., and J. S. Fletcher. 1993b. Assessment of published literature on the uptake, accumulation, and translocation of heavy metals by vascular plants. Chemosphere. 27:1669-1680.

Raskin, I. 1996. Phytoremediation, In: Phytoremediation. Proceedings of International Business Communications Conference, held in Virginia, Arlington, May 8-10. Raskin, I., P.B.A.N. Kumar, S. Dushenkov, and D.E. Salt. 1994. Bioconcentration of heavy metals by plants. Curr. Opin. Biotechnol. 5:285-290.

Reeves, R. D., and R. R. Brooks. 1983. Hyperaccumulation of lead and zinc by two metallophytes from mining areas of central Europe. Environ. Pollut. Ser. A. 31:277-285.

Rock, S. A. 1997. Phytoremediation. Standard Handbook of Hazardous Waste Treatment and Disposal, H. Freeman (ed.). McGraw Hill.

RTDF. 1998. Summary of the Remediation Technologies Development Forum Alternative Covers Assessment Program Workshop. February 17-18, 1998, Las Vegas, NV. http://www.rtdf.org.

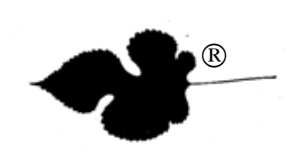
(C)2004 Purdue University 
Salt, D.E., M. Blaylock, N.P.B.A. Kumar, V. Dushkenov, B.D. Ensley, I. Chet, and I. Raskin. 1995. Phytoremediation: a novel strategy for the removal of toxic metals from the environment using plants. Biotechnol. 13:468-474.

Salt, D.E., R.D. Smith, and I. Raskin. 1998. Phytoremediation. Annu. Rev. Plant Physiol. Plant Mol. Biol. 49:643-668.

Schnoor, Jerald L. 1997. Phytoremediation of soil and groundwater. Technology Evaluation Report (TE-98-01), Ground-Water Remediation Technologies Analysis Center.

Schnoor, Jerald L. 2002. Phytoremediation of soil and groundwater. Technology Evaluation Report (TE-02-01), Ground-Water Remediation Technologies Analysis Center.

Schnoor, J. L., L. A. Licht, S. C. McCutcheon, N. L. Wolfe, and L. H. Carreira. 1995a. Phytoremediation of organic and nutrient contaminants. Environ. Sci. Technol. 29:318A-323A.

Schnoor, Jerald L., Louis A. Licht, Steven C. McCutcheon, N. Lee Wolfe, and Laura H. Carreira. 1995b. Phytoremediaiton of organic and nutrient contaminants. Environ. Sci. Technol. 29(7):318A-323A.

Schwab, A.P. 1992. Chemical and physical characterization of soils. Conf. Proc. Hazardous Substance Res. Center. pp. 326-344.

Terry, N. 1996. The Use of Phytoremediation in the cleanup of selenium polluted soils and waters. International Phytoremediation Conference. May 8-10, 1996. Arlington, VA.

U.S. Department of Energy (DOE). 1994. Summary report of a workshop on phytoremediation research needs, held at Santa Rosa, California, June 24-26. Report DOE/EM-0224. Oak Ridge, Tennessee.

USEPA. 1998. Phytoremediation handbook for site managers-Draft. USEPA, June 1998.

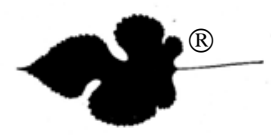

PhytoRemediate $^{\circledR}$ : Phytoremediation Decision Guide for C2004 Purdue University Transportation Engineers 
USEPA. 2000. Introduction to phytoremediation. EPA/600/R-99/107, National Risk Management Research Laboratory, Office of Research and Development, Cincinnati, $\mathrm{OH}$.

USEPA. 2002. Phytoremediation of volatile organic compounds in groundwater: Case studies in plume control, Office of Research and Development, Technology Innovation Office, Washington, D.C.

Van Den Bos, Amelie. 2002. Phytoremediaiton of volatile organic compounds in groundwater: Case studies in plume control. USEPA, Office of Solid Waste and Emergency Response.

USEPA, 1998. Phytoremediation handbook for site managers-Draft. USEPA, National Risk Management Research Laboratory, Cincinnati, Ohio.

USEPA, 2000. Introduction to phytoremediation (EPA/600/R-99/107). USEPA, Office of Research and Development, Washington, DC.

USEPA, 2001. Brownfields technology primer: Selecting and using phytoremediation for site cleanup (EPA/542-R-01-006). USEPA, Office of Solid Waste and Emergency Response, Washington, DC. 
USEPA. 2000. Introduction to phytoremediation. EPA/600/R-99/107, National Risk

Management Research Laboratory, Office of Research and Development, Cincinnati, $\mathrm{OH}$.

USEPA. 2002. Phytoremediation of volatile organic compounds in groundwater: Case studies in plume control, Office of Research and Development, Technology Innovation Office, Washington, D.C.

Van Den Bos, Amelie. 2002. Phytoremediaiton of volatile organic compounds in groundwater: Case studies in plume control. USEPA, Office of Solid Waste and Emergency Response.

USEPA, 1998. Phytoremediation handbook for site managers-Draft. USEPA, National Risk Management Research Laboratory, Cincinnati, Ohio.

USEPA, 2000. Introduction to phytoremediation (EPA/600/R-99/107). USEPA, Office of Research and Development, Washington, DC.

USEPA, 2001. Brownfields technology primer: Selecting and using phytoremediation for site cleanup (EPA/542-R-01-006). USEPA, Office of Solid Waste and Emergency Response, Washington, DC.

Formatted: Font: $10 \mathrm{pt}$

PhytoRemediate $^{\circledR}$ : Phytoremediation Decision Guide for Transportation Engineers

(C2004 Purdue University 